\title{
LYSIMETER TESTS OF SRP WASTE FORMS
}

R. L. HOOKER

R. W. ROOT, JR.

\section{TIS FILE RECORD COPY

E. I. du Pont de Nemours \& Co. Savannah River Laboratory

Aiken, SC 29808 
This report was prepered by E. I. du Pont de Nemours and Company (Ou Pont) for the United States Depertment of Energy under Contract DE-ACO9-76Sf00001 and is an account of work parformect under that Contract. Neither the United Stetes, the United Steres Depertment of Energy nor Du Pont, nor any of their employees, makes any warrenty, express or implied, or assumes any legal liability or responsibillity for the accuracy, completeness, or usefulness of any intormation, appuratus, product, or precess diectosed herein, or represents that its use will not infringe privenely owned rights. Reference herein to eny specific commerical product, procees, or service by trade name, mark, manufacturer, or otherwise does not necessarily constitute or imply endiorsement, recommendation, or favoring of same by Du Pont or by the United States Government or any agency thereof. The views

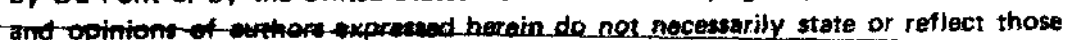
oi the Unitied States Guvernment or any agency thereof.

Printed in the United States of America

Availuble from

Netional Technical Information Service

U. S. Depertment of Commorce

5285 Port Royal Road

Springfield, Virginia 22161

Prioe: Printed Copy A04; Microfiche AD1 


\section{LYSIMETER TESTS OF SRP WASTE FORMS}

R. L. HOOKER

R. W. ROOT, JR.

Savannah River Laboratory

E. I. du Pont de Nemours \& Co.

Aiken, SC 2.9808

Approved by:

E. L. Albenesius, Research Manager

Waste Disposal Technology

Publication Date: May 1981

\section{E. I. du Pont de Nemours \& Co. Savannah River Laboratory Aiken, SC 29808}

PREPARED FOR THE U. S. DEPARTMENT OF ENERGY UNDER CONTRACT DE-ACO9-76SRO0001 
A field study, estimated to last 10 years, has been started to define leaching and migration rates of radionuclides from typical SRP buried wastes. The study utilizes 42 lysimeters (6-ft or 10-ft diameter by 10-ft deep) which have been charged with soil and waste to simulate burial ground conditions. Eight waste forms were selected for the study, which represent the bulk of the wastes generated at SRP. This report describes the lysimeter design, the physical and radiological characteristics of the wastes, and the experimental approach. Calculations have also been made which predict the migration of various radionuclides in the lysimeter soil. The calculations should provide guidance during the course of the study, and are the basis of recommendations made for collecting and interpreting data so that important parameters of migration can be evaluated. 
i) 1

Introduction 7

Lysimeter Design and Installation 8

Waste Forms and Characteristics 8

Lysimeter Operation 21

Lysimeter Modeling 21

Recommendations for Field Tests 35

Conclusions 37

Acknowledgments 39

References $\quad 40$

Append ix 41

\section{1)}




\section{LIST OF FIGURES}

1 Lysimeter Cross Section 9

2 Plot Plan Lysimeter Site 10

3 Lysimeter Layout - Typical Set of Five 11

4 Separations Laboratory Glove Box Waste in Lysimeter 13

5 Reactor Moderator Resin Being Dumped into Lysimeter 14

6 Plutonium Finishing Line Job Control Waste in Lysimeter 15

7 SRL High Level Caves Waste in Lysimeter 16

8 Separations Canyon Pipe Jumpers in Lysimeter 17

9 Separations Area Laboratory (BIdg 772-F) Waste in Lysimeter 18

10 Reactor Area Scrap Metal in Lysimeter 19

11 Portable Filter-Blower Assembly 20

12 Long-Handled Knives Used to Open Waste Packages in Lysimeter 22

$13{ }^{60}$ Co in Soil water vs. Depth in Soil 26

$1490_{\mathrm{Sr}}$ : in Soil Water vs. Depth in Soil 27

$15 \quad{ }^{106} \mathrm{Ru}$ in Soil Water vs. Depth in Soil 28

$16 \quad{ }^{137} \mathrm{Cs}$ in Soil Water vs. Depth in Soil 29

$17238 \mathrm{Pu}$ in Soil Water vs. Depth in Soil 30

$18{ }^{239} \mathrm{Pu}$ in Soil Water vs. Depth in Soil 31

19 Tritium in Soil Water vs. Time (at Bottom of Lysimeter) 32

$20 \quad 137 \mathrm{Cs}$ in Soil water vs. Depth in Soil (Effect of Water Velocity) 33

$21239 \mathrm{pu}$ in Soil water vs. Depth in Soil (Effect of Source Depletion) 36

$22 \quad{ }^{106} \mathrm{Ru}$ in Sump Water (Effect of $\mathrm{K}_{\mathrm{d}}$ ) 38 
LIST OF TABLES

1 Waste Types Buried in Lysimeters 12

2 Estimated Minimum $C / C_{0}$ for Detection of Radioisotopes 34

A-1 Comprehensive Lysimeter Loading Data 42 
The Savannah River Plant (SRP) site occupies an approximately circular area $(192,000$ acres) in South Carolina bounded on the southwest by the Savannah River and centered approximately 25 miles southeast of Augusta, Georgia. Solid radioactive defense wastes are stored in one centrally located burial ground. The original 76-acre burial ground was placed in operation in 1953 and 119 acres were added in $1972.1,2$

Studies at the Savannah River Laboratory (SRL) are currently investigating the long-term consequences of past and current burial ground operations. These studies involve radionuclide chemistry, trench sampling, groundwater modeling and monitoring, and waste migration.

A field study was recently begun which uses lysimeters to define leaching and migration rates of radionuclides from typical SRP buried wastes. A lysimeter measures water percolation through soils and determines the soluble constituents removed by drainage. Lysimeters are typically used in agricultural studies, but can be adapted for radionuclide migration studies. ${ }^{3}$ Lysimeters $(6-\mathrm{ft}$ or $10-\mathrm{ft}$ diameter by $10-\mathrm{ft}$ deep) were installed at SRP to function as miniature burial grounds in which the amount and location of the wastes are controlled and provisions are made for collecting and sampling percolating rainwater. The rate at which radioactivity is leached from waste and the rate the activity moves through soil are primary factors in evaluating the future impact of buried waste on the environment and on man.

The wastes buried in the lysimeters are typical of those generated by the wide variety of $\mathrm{plant}$ and laboratory operations. The wastes include irradiated reactor fuel housings, ion exchange resins, waste plastics and tools from the plutonium finishing line, and laboratory glassware. The wastes contain $238 \mathrm{Pu},{ }^{239} \mathrm{Pu}, 60^{\circ} \mathrm{Co},{ }^{137} \mathrm{Cs},{ }^{90} \mathrm{Sr},{ }^{14} \mathrm{C}$, and other miscellaneous fission and activation products. Leaching and migration of plutonium is of interest, even though no significant amount of plutonium is currently being buried, because about $4000 \mathrm{Ci}$ of $238 \mathrm{Pu}$ and $400 \mathrm{Ci}$ of $239 \mathrm{Pu}$ were buried unencapsulated in trenches during the early years of SRP burial ground operation.

The lysimeter program is expected to continue for approximately 10 years, during which time leachate water samples will be taken. For those lysimeters which show no radioactivity in the leachate after 10 years, soil samples can be taken by excavation or coring to determine the extent of leaching and migration. Results from the study will be used in a mathematical model to calculate the long-term potential dose-to-man from the buried wastes. 


\section{Lysimeter Design and Installation}

The lysimeters used by SRL were constructed of corrugated aluminum pipe sections (12 gage) which were coated with asphalt and are normally used for culverts (Figure 1). The bottom of the 1ysimeter is sloped to drain the percolate water to a low point where it can be pumped out. Because a few of the first lysimeters installed leaked after being loaded with soll and waste, the remainder were provided with a 20-mil thick polyvinylchloride liner and tested to ensure a leak rate below $0.15 \mathrm{~L} / \mathrm{hr}$.

Because the lysimeter site is between the old and the new burial grounds, soil, weather, and atmospheric fallout should be similar to that encountered in the burial grounds (Figure 2). There are five lysimeters for each of eight waste forms, plus two lysimeters in which no waste has been placed. The latter two lysimeters are used as controls to determine if airborne contamination from the nearby burial ground, separations areas, or regional atmospheric fallout is influencing lysimeter sample results.

Figure 3 shows a layout view of a typical set of five lysimeters. One of the lysimeters is $10 \mathrm{ft}$ in diameter and the other four are $6 \mathrm{ft}$ in diameter. Holding tanks (6-ft diameter $\times 6-\mathrm{ft}$ high) are provided to receive all of the water removed from the lysimeters which contain transuranic waste.

The soil placed in the lysimeters was selected as being typical SRP burial ground soil. It was accumulated and then mixed with large earth-moving equipment so that variations among lysimeters would be minimized. Samples of soil were taken and will be characterized. Soil core samples can also be taken without disturbing the waste by entry through the side of the lysimeters. The latter may be necessary if the radionuclide is retained strongly by the soil such that it is not detectable in water collected in the sump. The data obtained will be used to calculate leaching and migration rates from the emplaced wastes.

\section{Waste Forms and Characteristics}

Eight waste forms were selected that represent most of the wastes in the SRP burial ground (Table 1). The wastes come from multiple generation points on the plant and may contain a number of radionuclides in various forms. A comprehensive description of the waste forms, the quantity and method of measurement of the radioactivity present in each lysimeter, and the date of waste emplacement are given in the Appendix (Table A-1). 


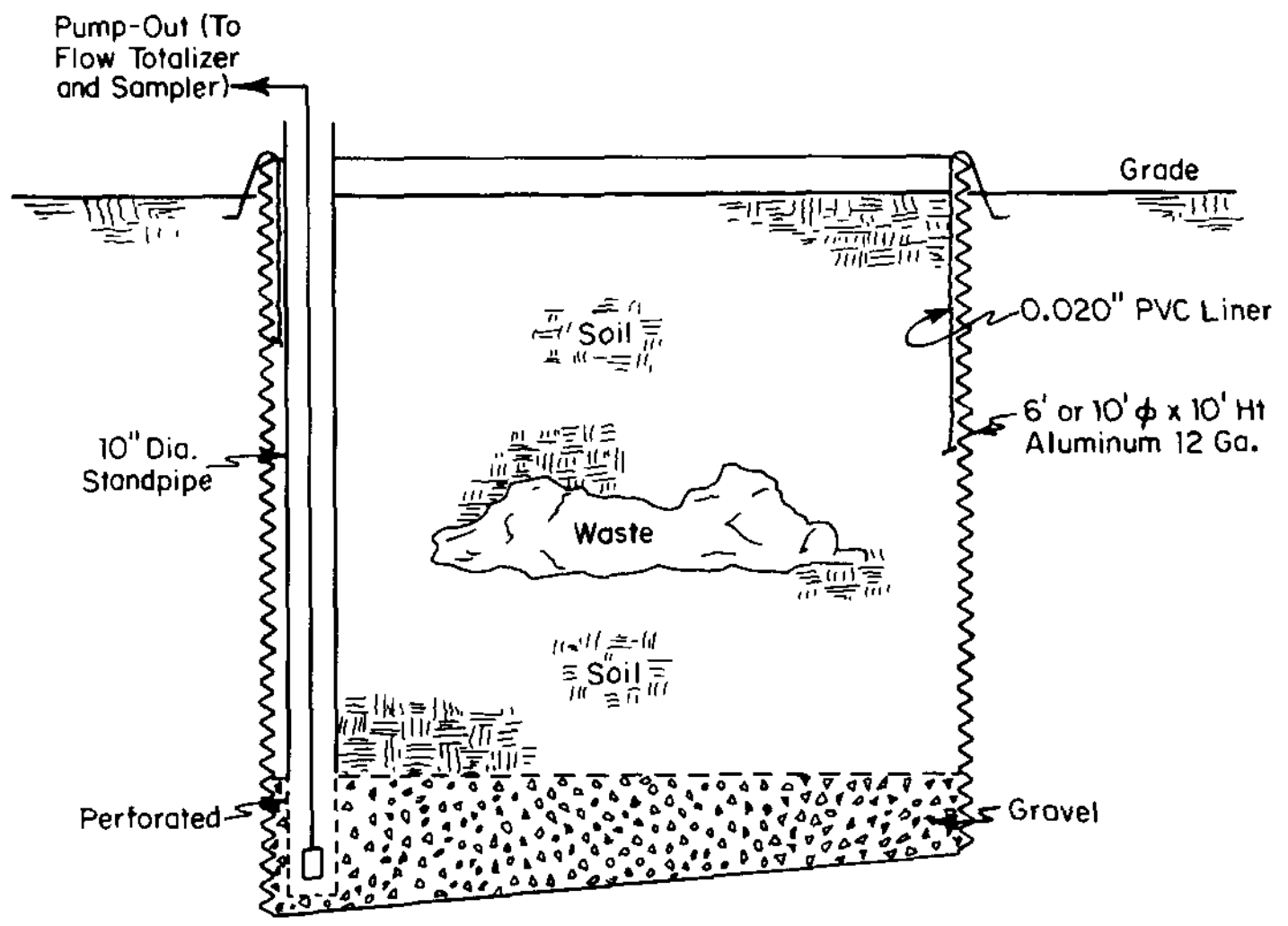

FIGURE 1. Lysimeter Cross Section 


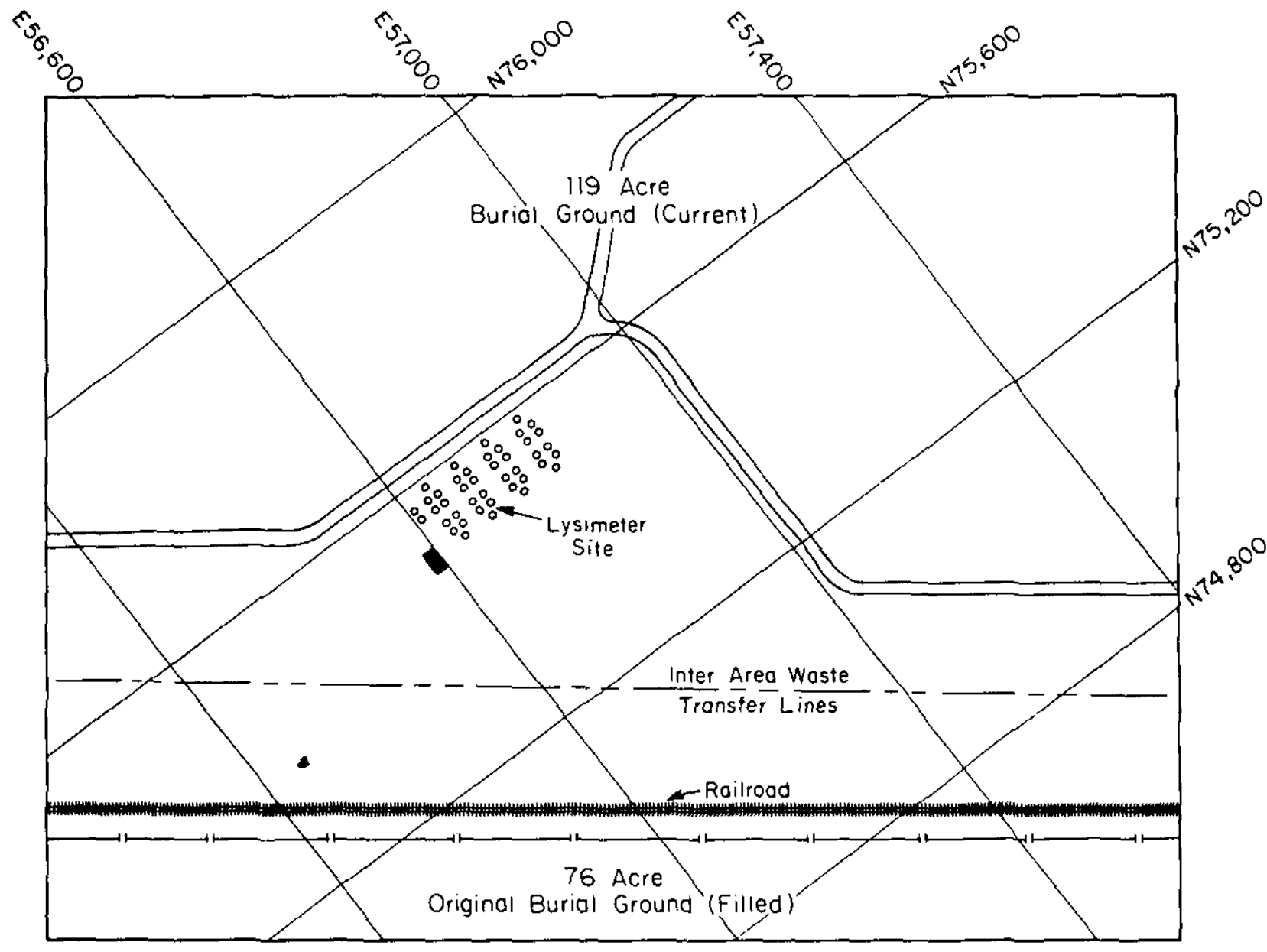

FIGURE 2. Plot P1an of Lysimeter Site 

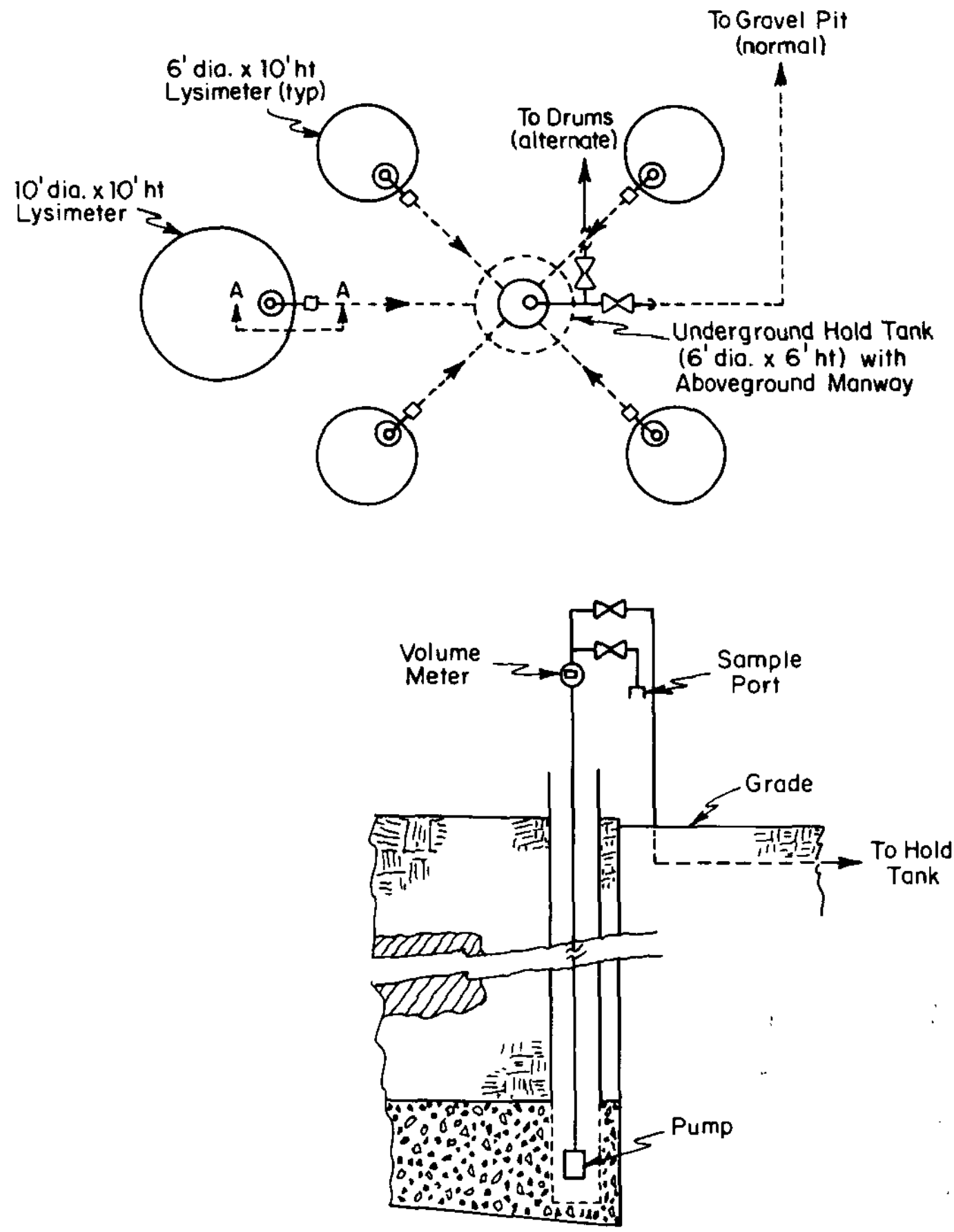

SECTION A-A (Typ)

FIGURE 3. Lysimeter Layout - Typical Set of Five 
TABLE 1

Was te Types Buried in Lysimeters

Waste Forms

Separations Laboratory Glove

Box Waste

Reactor Moderator Deionizer

Res in

Plutonium Finishing Line Job

Control Waste

SRL High Level Caves and Actinide Materials Facility (AMF) Waste

Separations Canyon Pipe Jumpers

Separations Area Laboratory Waste

Separations Area Canyon Job Control Waste

Reactor Area Scrap Metal
Primary Radioactivity Type

${ }^{238} \mathrm{Pu}$

Fission products and activation products

${ }^{239} \mathrm{Pu}$

$238 \mathrm{Pu}$, fission products, and activation products

${ }^{238} \mathrm{Pu},{ }^{239} \mathrm{Pu}$ and a small amount of fission products

Fission products

Fission products

Activation products

Figures 4 through 10 are photographs of wastes taken during or after placement in lysimeters. Most of the views are through an opening in a plastic cover placed over the lysimeter to control airborne contamination. No photograph was taken of Separations Canyon Job Control waste, but its appearance is similar to Separations Laboratory Glove Box Waste.

Figure 11 shows the portable filter-blower which was fabricated for this program and used to control airborne contamination during charging of the lysimeter by inducing inflow of air through an opening in the plastic cover over the top of the lysimeter. The unit has two high efficiency particulate air (HEPA) filters in series. The design bas is of the filter-blower was to maintain an inward air flow velocity of $150 \mathrm{ft} / \mathrm{min}$ through the opening in the plastic. The blower is powered with a $10 \mathrm{HP}$ gasoline engine. Although the lysimeter loading operations were conducted outdoors in ambient air currents, spread of airborne contamination was successfully avoided with this apparatus. 


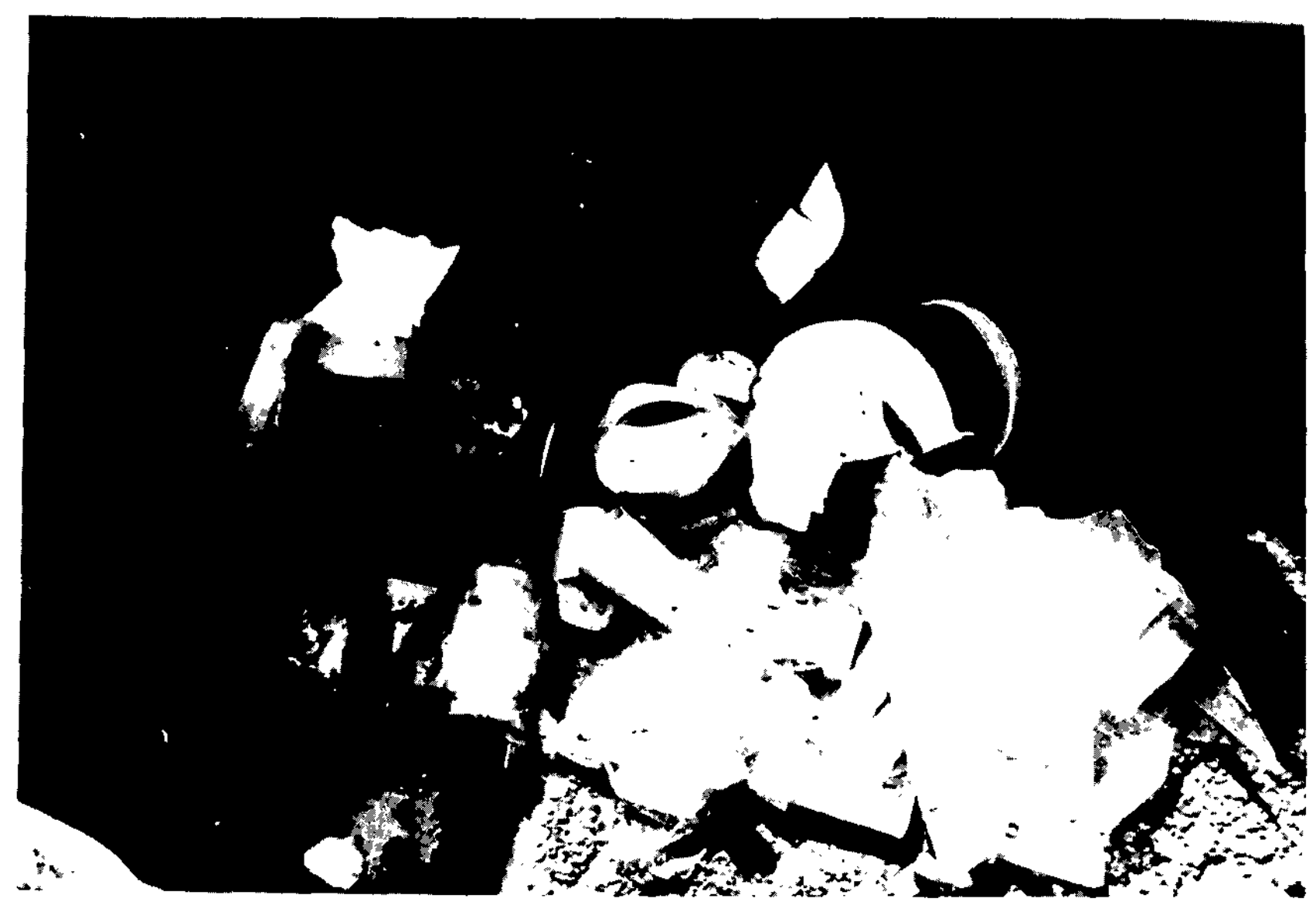

FIGURE 4. Separations Laboratory Glove Box Waste in Lysimeter 


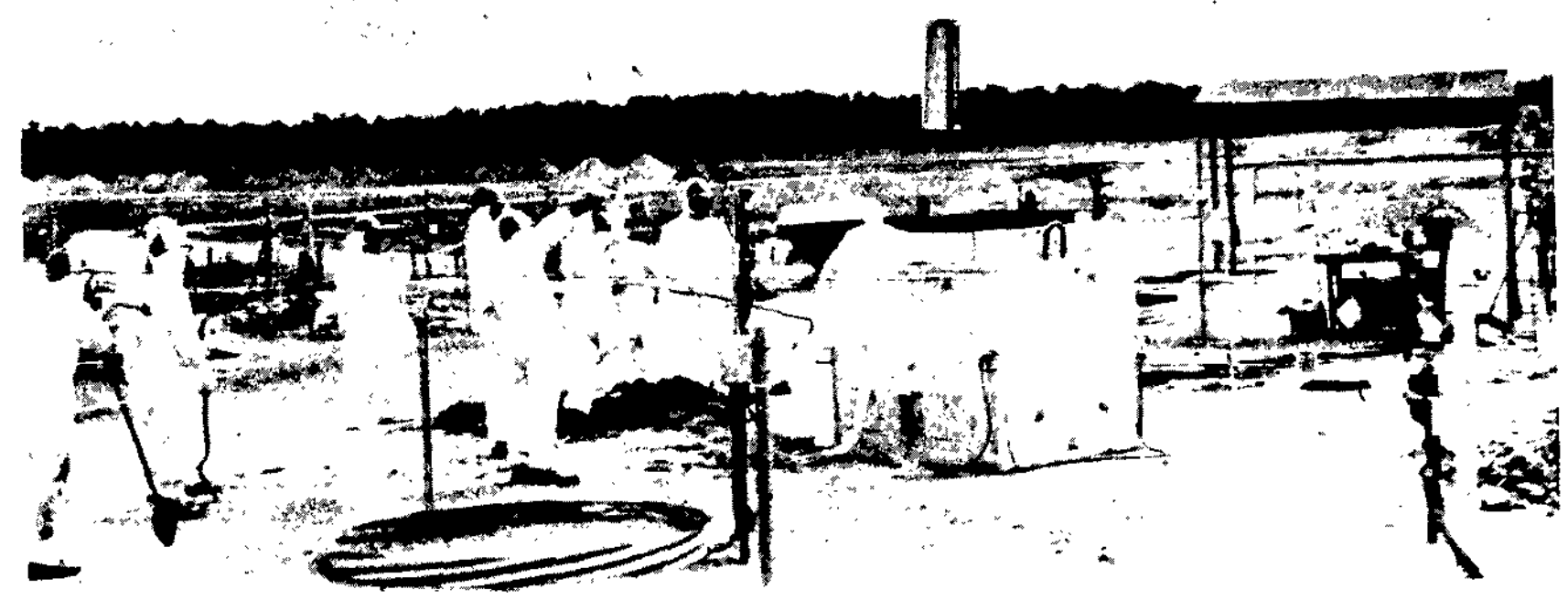

FIGURE 5. Reactor Moderator Resin Being Dumped into Lysimeter 


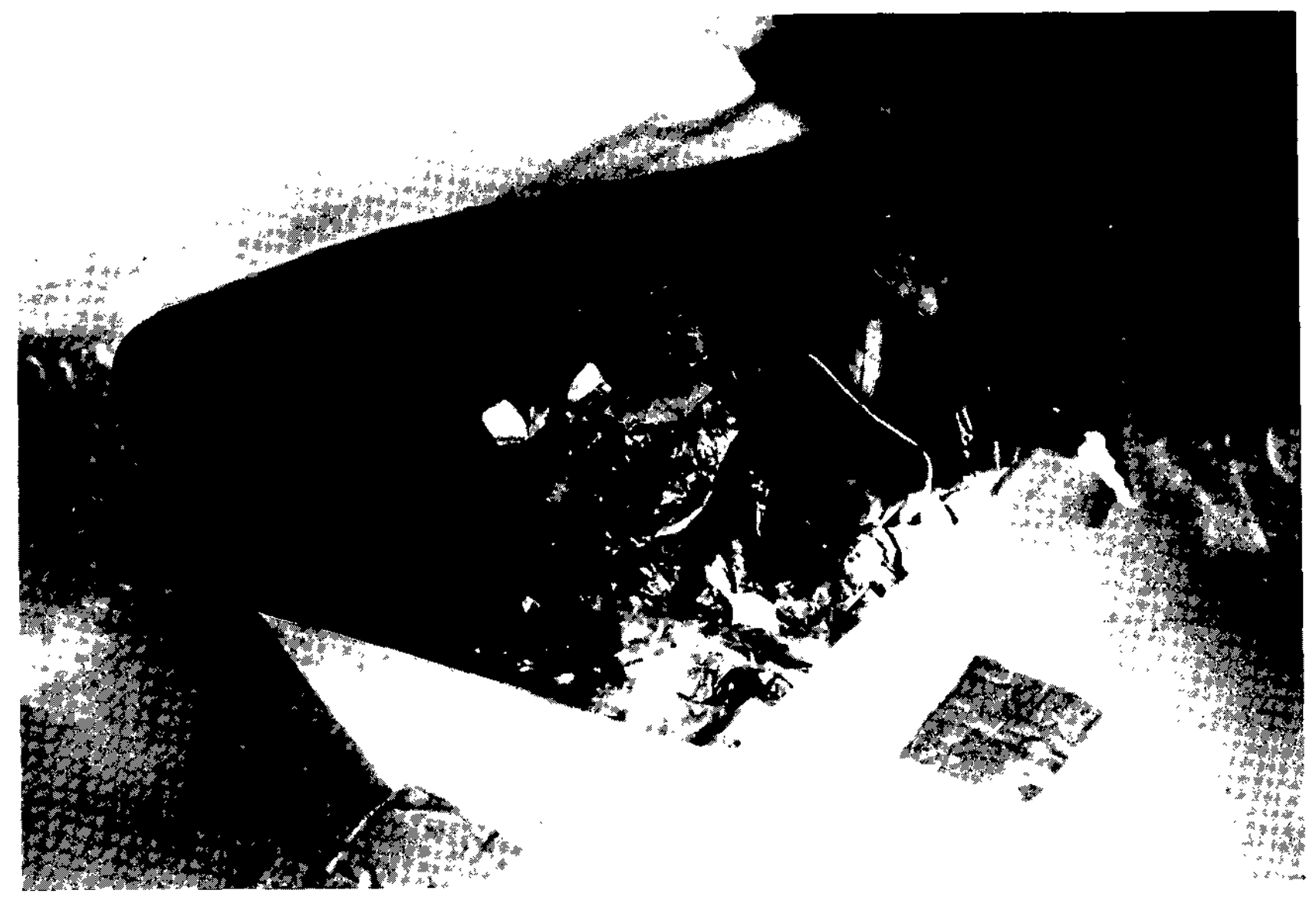

FIGURE 6. Plutonium Finishing Line Job Control Waste in Lysimeter

$\therefore$ 


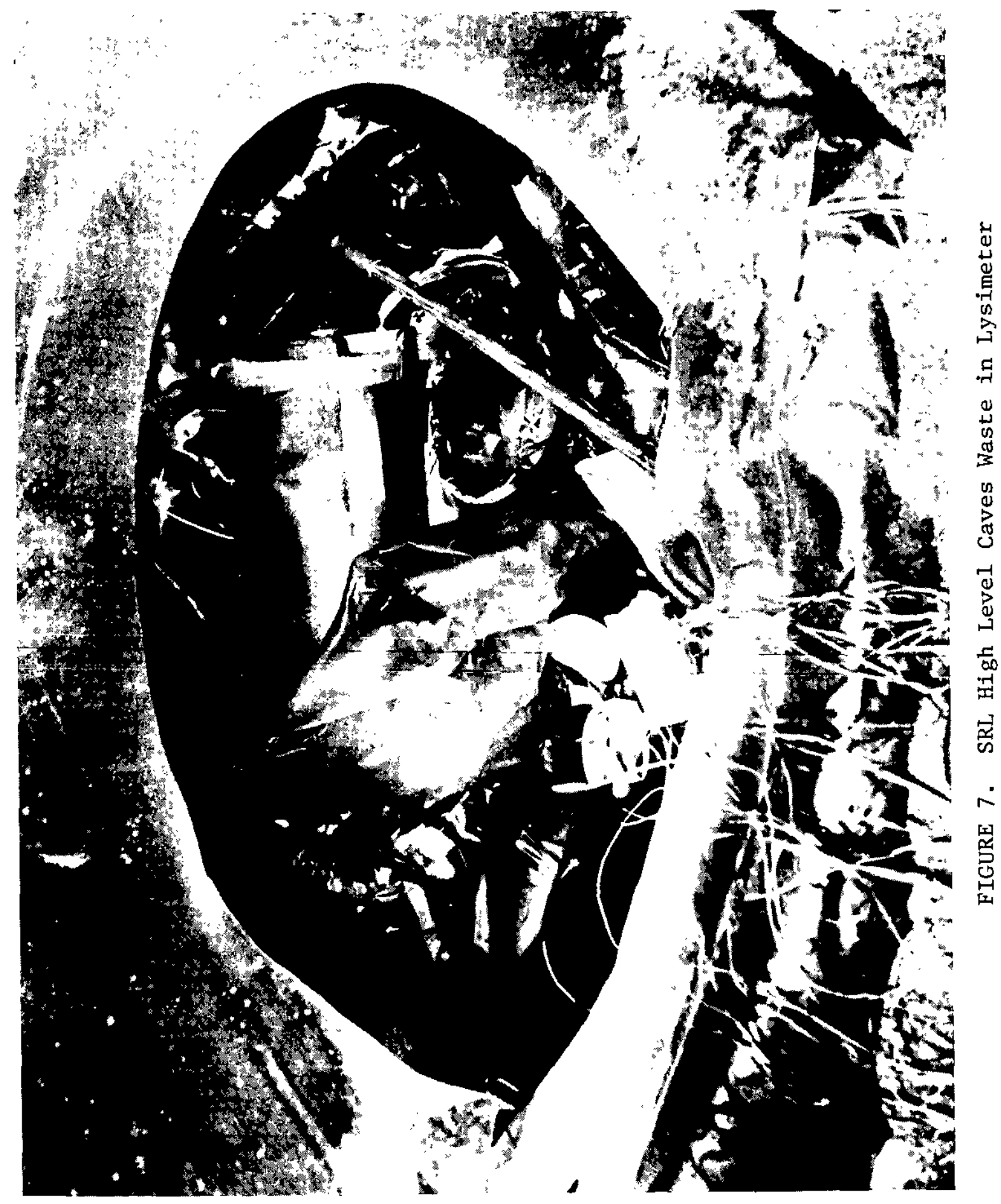




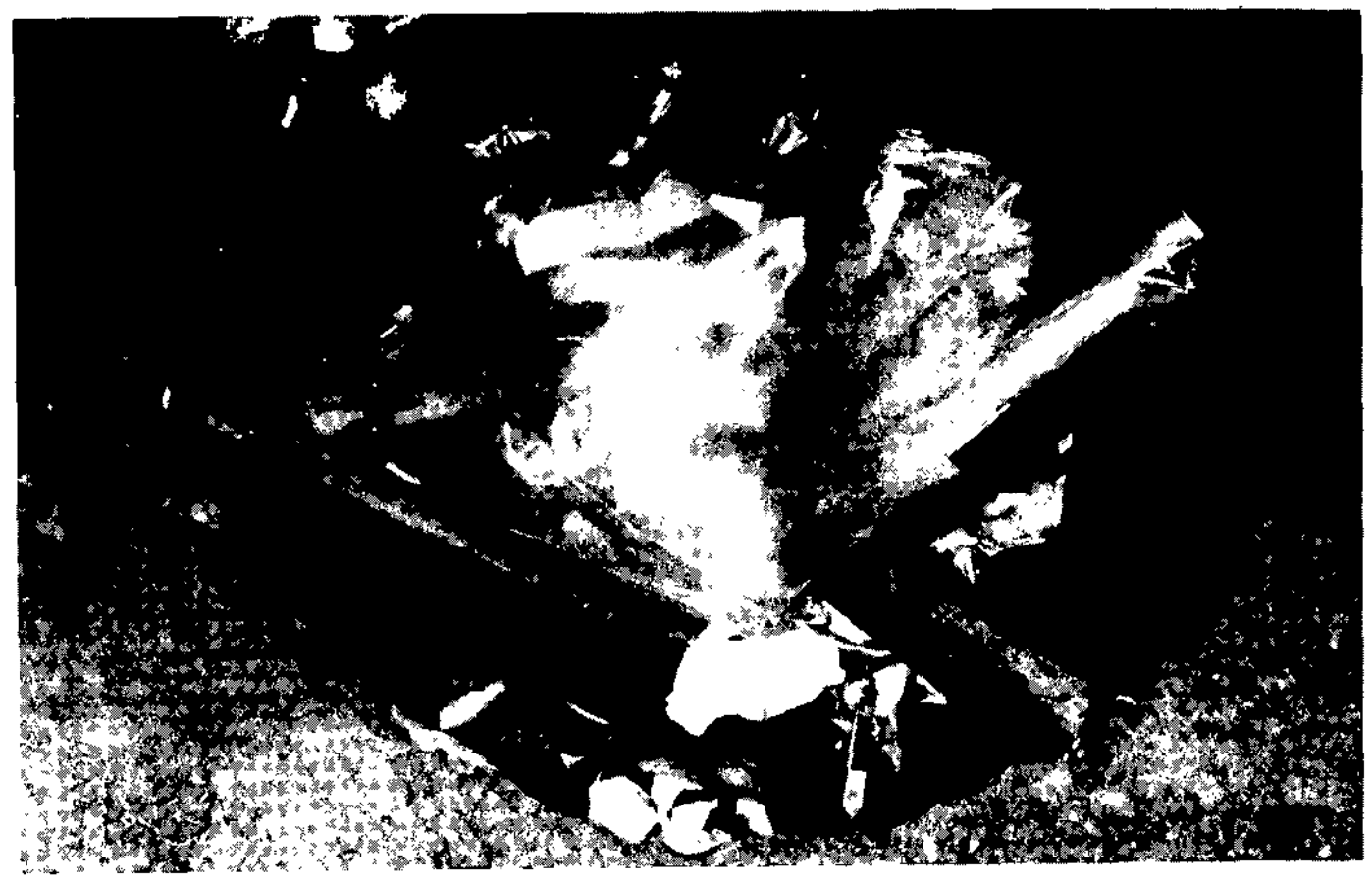

FIGURE 8. Separations Canyon Pipe Jumpers in Lysimeter 


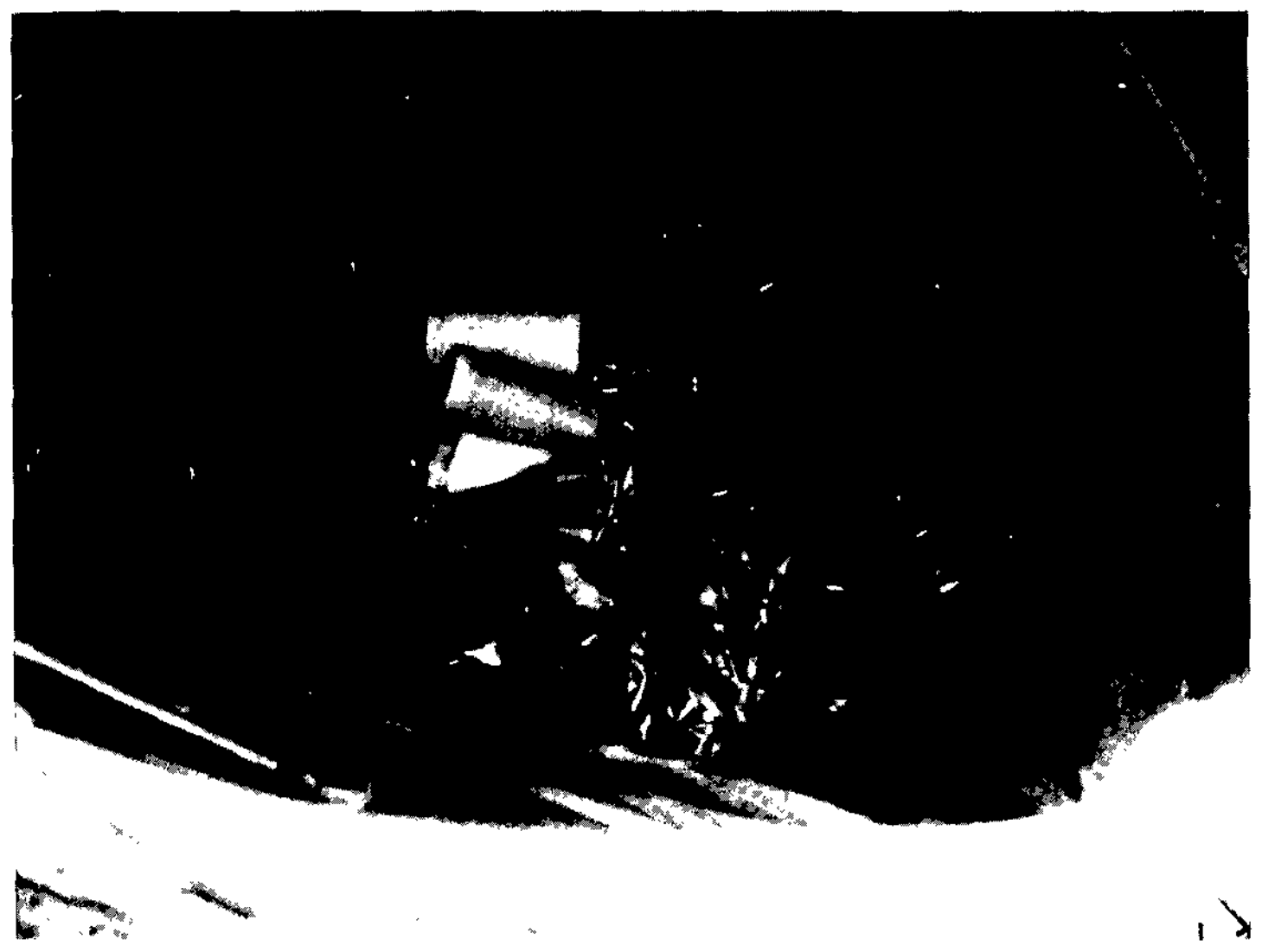

FIGURE 9. Separations Area Laboratory (BIdg. 772-F) Waste in Lysimeter 


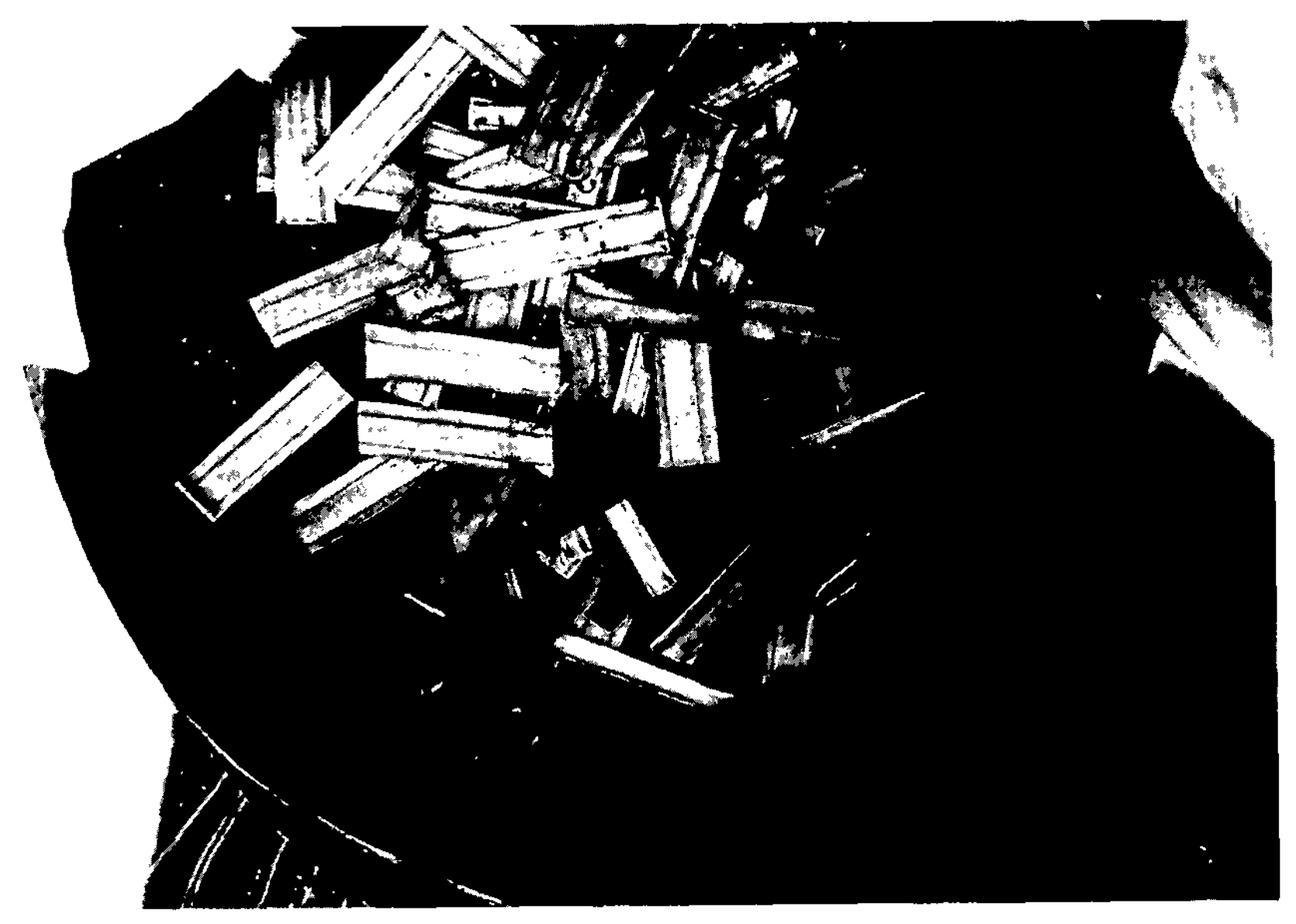

FIGURE 10. Reactor Area Scrap Metal in Lysimeter 


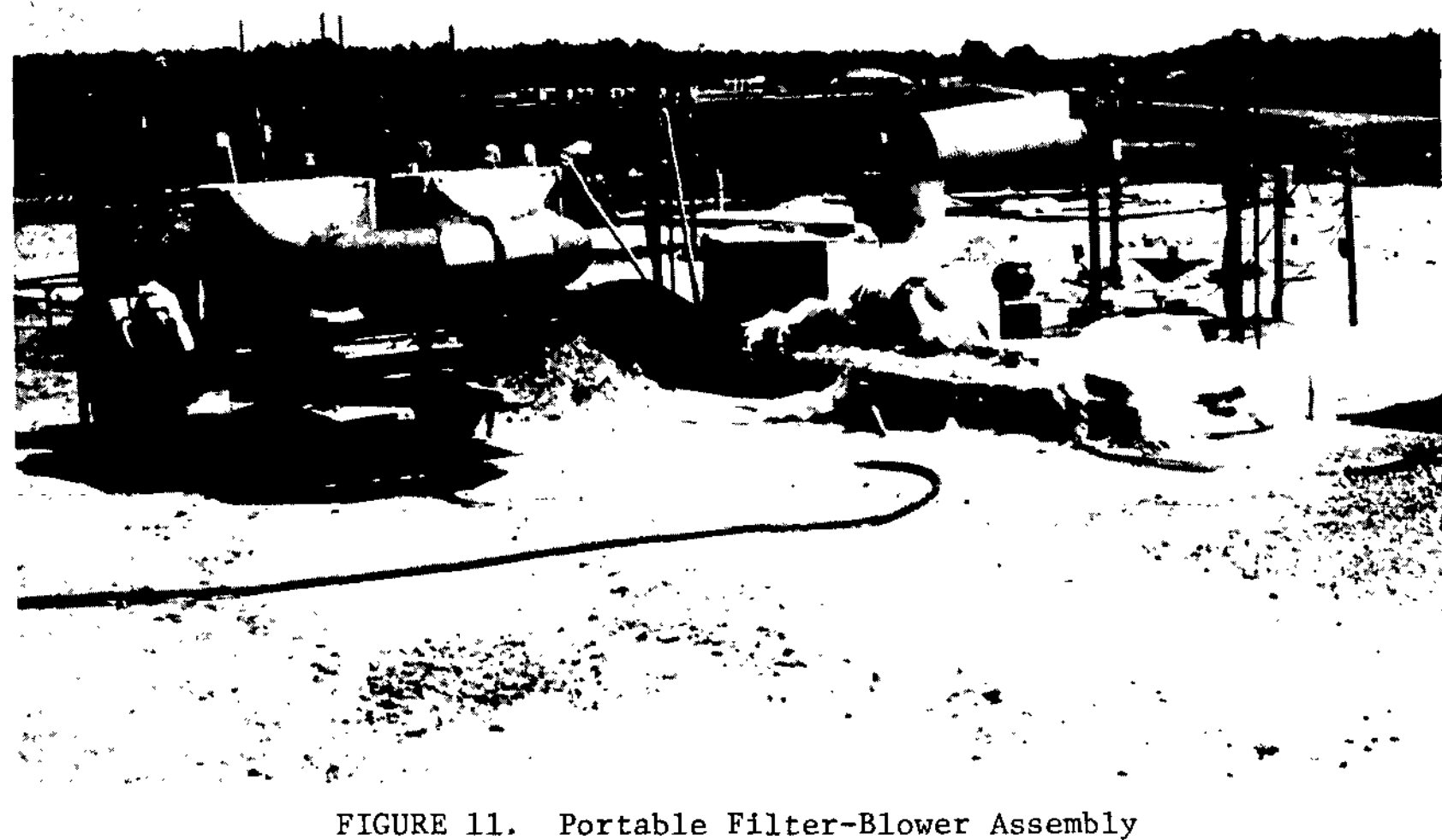

FIGURE 11. Portable Filter-Blower Assembly 
Figure 12 shows long-handled knives which were used for opening the waste packages which were placed in the lysimeters.

Packages were intentionally breached to allow leaching to start uniformly soon after the lysimeters were loaded.

\section{Lysimeter Operation}

Two of the 6-ft diameter lysimeters of each set are operated in an "unsaturated" mode; i.e., with the water level maintained well below the waste zone. The other two 6-ft diameter lysimeters of each set are operated in a "saturated" mode; i.e., with the water level maintained above the waste zone. The saturated mode simulates a condition which sometimes exists in trenches, due to perched water at the interface between undisturbed and backfilled soil at the trench bottom. The $10-\mathrm{ft}$ diameter lysimeter is operated in the unsaturated mode. This lysimeter was made large enough to support the root system of a pine tree. Pensacola bahia grass, the same vegetative cover used in the SRP burial ground to prevent erosion, is planted in all the lysimeters. The grass will be limed and fertilized at the same rate as the burial ground. Radionuclide uptake by the grass and by the pine trees will be measured under these conditions where the location, amount, and type of radionuclide are known.

Each lysimeter has a sump placed at the low point to remove percolate water (Figure 3). A pump is placed in the sump with its suction opening at the minimum desired water level. A meter indicates the valume of water removed. Periodic attendance of the lysimeter is required to maintain and confirm that the water levels do not exceed the intended levels, particularly following periods of heavy rainfall. Currently, the pumps are operated manually, but in the future the pumps will automatically turn on or off to maintain a water level within a 6-in. operating range. Water level indication is also planned to confirm that the pumps are operating satisfactorily. Water removed from the lysimeters is sampled and normally disposed of in gravel-lined pits. If radioactivity is detected above certain limits, the water will be collected and routed to a Separations Area for disposal.

\section{Lys imeter Modeling}

Modeling of radionuclide movement through the SRP lysimeters was done to help predict when measurable levels of activity might be seen in effluent water and thus provide guidance for long-term lysimeter operation. The parameters identified as important for transport through the lysimeters can be used to link laboratory measurements with actual radionuclide migration in the burial trenches. 


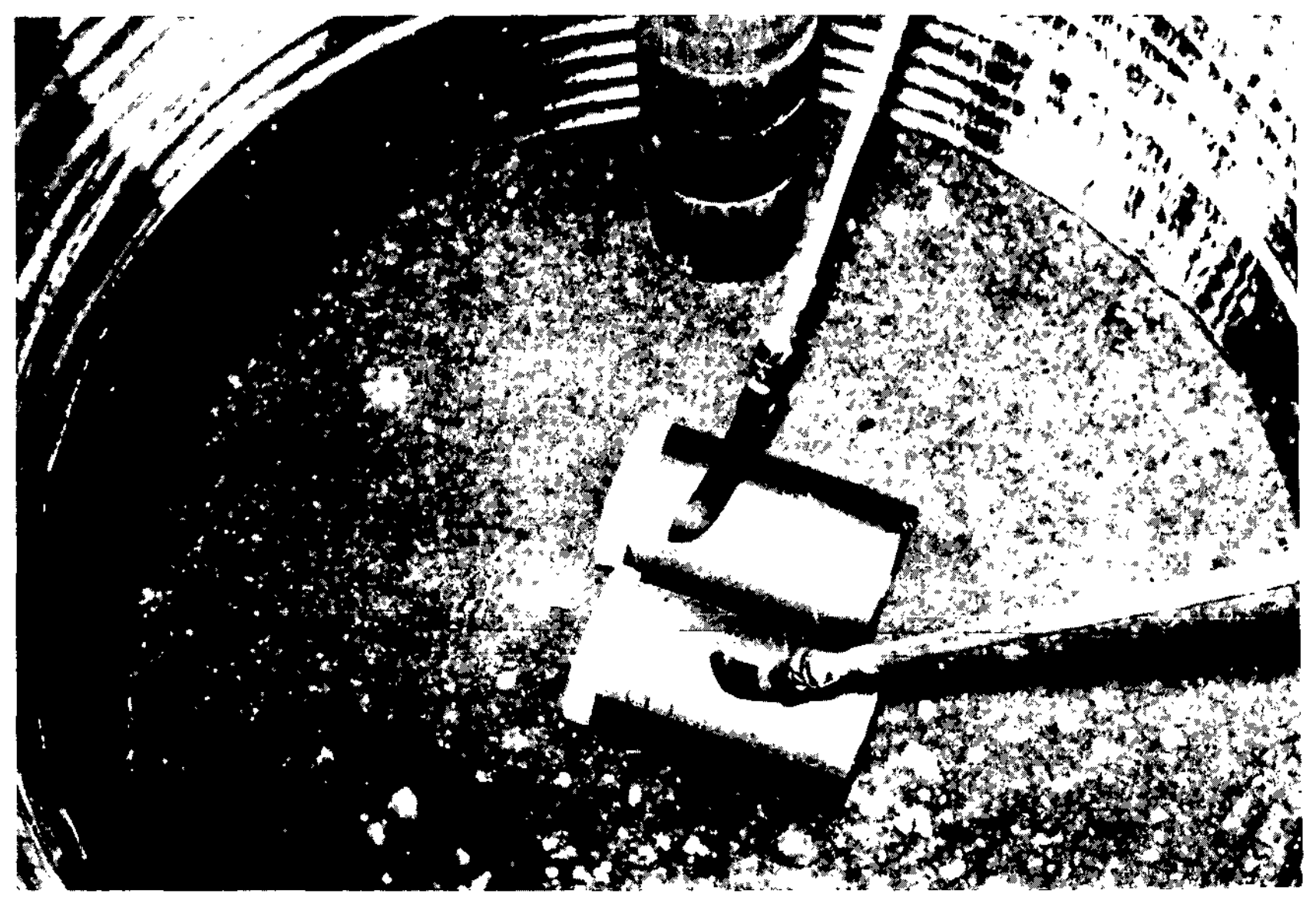

FIGURE 12. Long-Handled Knives Used to Upen waste racnage, in Lysimeter 


\section{Transport Equation}

The 3-ft layer of soil beneath the waste zone (Figure 1) retards movement of most radionuclides by adsorption and ion exchange. The time of appearance and the concentration of a given radionuclide in the water collected at the bottom of the lysimeter will depend primarily on four factors: the leach rate, the water velocity, the distribution coefficlent of the radionuclide between the soil and soil water, and the dispersion coefficient. The leach rate and rainfall combine to set the concentration $\left(C_{o}\right)$ of the radionuclide in the soll water just below the waste.

Radionuclide movement downward through the lysimeter was modeled with a one-dimensional convective-dispersive solute transport equation:

$$
\frac{\partial C}{\partial t}+v \frac{\partial C}{\partial x}=D \frac{\partial^{2} C}{\partial X}-K C
$$

Boundary conditions appropriate to the lysimeter system are:

$$
\begin{aligned}
& C=C_{0} e^{-\gamma t}, \text { at } X=0 \\
& C=0, \text { at } t=0 \text { and } X>0 \\
& \frac{\partial C}{\partial X} \rightarrow 0, \text { as } X \rightarrow+\infty
\end{aligned}
$$

The solution to this differential equation is given by Bear $^{4}$ and Cleary 5 as :

$$
\begin{aligned}
& c(x, t)=\frac{C_{0} e^{-\gamma t}}{2}\left[\exp \left(\frac{x V}{2 D}-\frac{x}{\sqrt{D}} \sqrt{A}\right) \bullet\right. \\
& \operatorname{erfc}\left(\frac{X}{2 \sqrt{D t}}-\sqrt{A t}\right)+\exp \left(\frac{x V}{2 D}+\frac{x}{\sqrt{D}} \sqrt{A}\right) \bullet \\
& \left.\operatorname{erfc}\left(\frac{X}{2 \sqrt{D t}}+\sqrt{A t}\right)\right]
\end{aligned}
$$


Notation used in the above equations is summarized below:

A

= Collected terms that account for source diminution:

$$
\begin{aligned}
& A=\frac{V^{2}}{4 D}+K-\gamma \\
& \mathrm{X}=\text { Distance in vertical direction }(\mathrm{L}) \text {. } \\
& C(x, t)=\text { Concentration of radionuclide at } x \text { and } t\left(\operatorname{activity} / L^{3}\right) \text {. } \\
& \mathrm{C}_{\mathrm{O}}=\text { Initial concentration of } \mathrm{radionuclide}\left(\operatorname{activity} / \mathrm{L}^{3}\right) \text {. } \\
& \text { D }=\text { Dispersion coefficient }\left(\mathrm{L}^{2} / \mathrm{t}\right) \\
& \mathrm{V}=\text { Velocity of radionuclide in groundwater }(\mathrm{L} / \mathrm{t}) \text {. This } \\
& \text { is related to the groundwater velocity by } \\
& v=v_{w}\left(\frac{1}{I+K_{d}^{R}}\right) \\
& \mathrm{V}_{\mathrm{w}} \quad=\text { Groundwater velocity }(\mathrm{L} / \mathrm{t}) \\
& \mathrm{K}_{\mathrm{d}} \quad=\text { Distribution coefficient of soil for radionuclide } \\
& \text { ( } \mathrm{L}^{3} / \mathrm{mass} \text { ). } \\
& \text { R }=\text { Retardation factor }=[\rho / \eta]\left(\text { Mass } / L^{3}\right) \\
& \rho=\text { Soil bulk density }\left(\operatorname{mass} / \mathrm{L}^{3}\right) \text {. Assumed }=1.5 \mathrm{~g} / \mathrm{cm}^{3} \\
& n=\text { Effective porosity (dimensionless). Assumed }=0.25 \\
& \text { t } \quad=\text { Time } \\
& \mathrm{K}=\text { Radioactive decay constant for radionuclide ( } 1 / t) \\
& \gamma=\text { Source depletion constant (may be a combination of } \\
& \text { leaching, radioactive decay, etc.) }(1 / t) \text {. }
\end{aligned}
$$


equation for modeling soil columns is well established, 6,7 The results given in this report represent the first efforts to model lysimeter performance.

\section{Mode1 Predictions}

Figures 13 through 18 illustrate the effect of the distribution coefficient $\left(K_{d}\right)$ on the movement of six isotopes through a lysimeter. $K_{d}$ is a measure of the ability of the soil to impede migration of radionuclides by adsorption or ion exchange. $\mathrm{K}_{\mathrm{d}}$ 's vary according to the fraction of sand, silt, or clay present in the soil; the radionuclide; and the physical and chemical properties of the soil and water. $K_{d}$ 's used for calculation and shown on each figure represent the highest and lowest values expected. Laboratory tests are planned to better define actual $\mathrm{K}_{\mathrm{d}}$ 's for SRP soil. Figures 13 through 18 also illustrate the effect of radioactive decay. For example, Figure 13 indicates that for $\mathrm{K}_{\mathrm{d}}=500,{ }^{60}$ Co activity could be detected in soil water about half a foot below the source after 2 years. The "Detection Limit" line on the graphs is based on assumptions of leaching and rainfall as given in Table 2 and discussed later. After 10 years measurable activity would have moved to about one foot below the source. However, after 100 years ${ }^{60} \mathrm{Co}$ would no longer be measurable at any location.

For Figures 13 through 18 , a vertical water velocity of 14 $\mathrm{ft} / \mathrm{yr}$ was assumed. This is about twice the vertical velocity of water in the unsaturated zone of the SRP burial ground, where there is opportunity for run-off to streams. 8 The 1ysimeter design does not permit run-off. This water is assumed to percolate downward. Figure 19 shows the effect of these two water velocities on tritium migration. Although no tritium is buried in the large lysimeters, it is an ideal isotope to illustrate flow effects since it has a very small $\mathrm{K}_{\mathrm{d}}$ on soil. This figure shows how the concentration at the bottom of the lysimeter varies with time. It also shows the effect of the dispersion coefficient (D). $D$ is primarily dependent on soil particle size, shape, and uniformity. Because the value of $D$ is not known, the relation $D=v \alpha$ was used, where $V$ is the radionuclide velocity, and $a$ is the dispersivity. The value for dispersivity $\alpha=1$ was used, based on estimates by Gupta and Greenkorn. ${ }^{5}$ Figure 19 indicates $\mathrm{C} / \mathrm{C}_{\mathrm{O}}$ is equal to about 0.25 at the lysimeter bottom ( $3 \mathrm{ft}$ ) after only about 0.1 year with a water volocity of $14 \mathrm{ft} / \mathrm{yr}$. Without dispersion, it would require 0.21 years $(3 \mathrm{ft} \div 14 \mathrm{ft} / \mathrm{yr}$ ) for tritium to reach this level.

Figures 13 through 20 show concentration ratios, but absolute values can be obtained by determining, or assuming, a $C_{0} \cdot C_{o}$, the concentration of a radionuclide in the soil water just below the waste, depends on the leach rate and the amount of rainfall. 


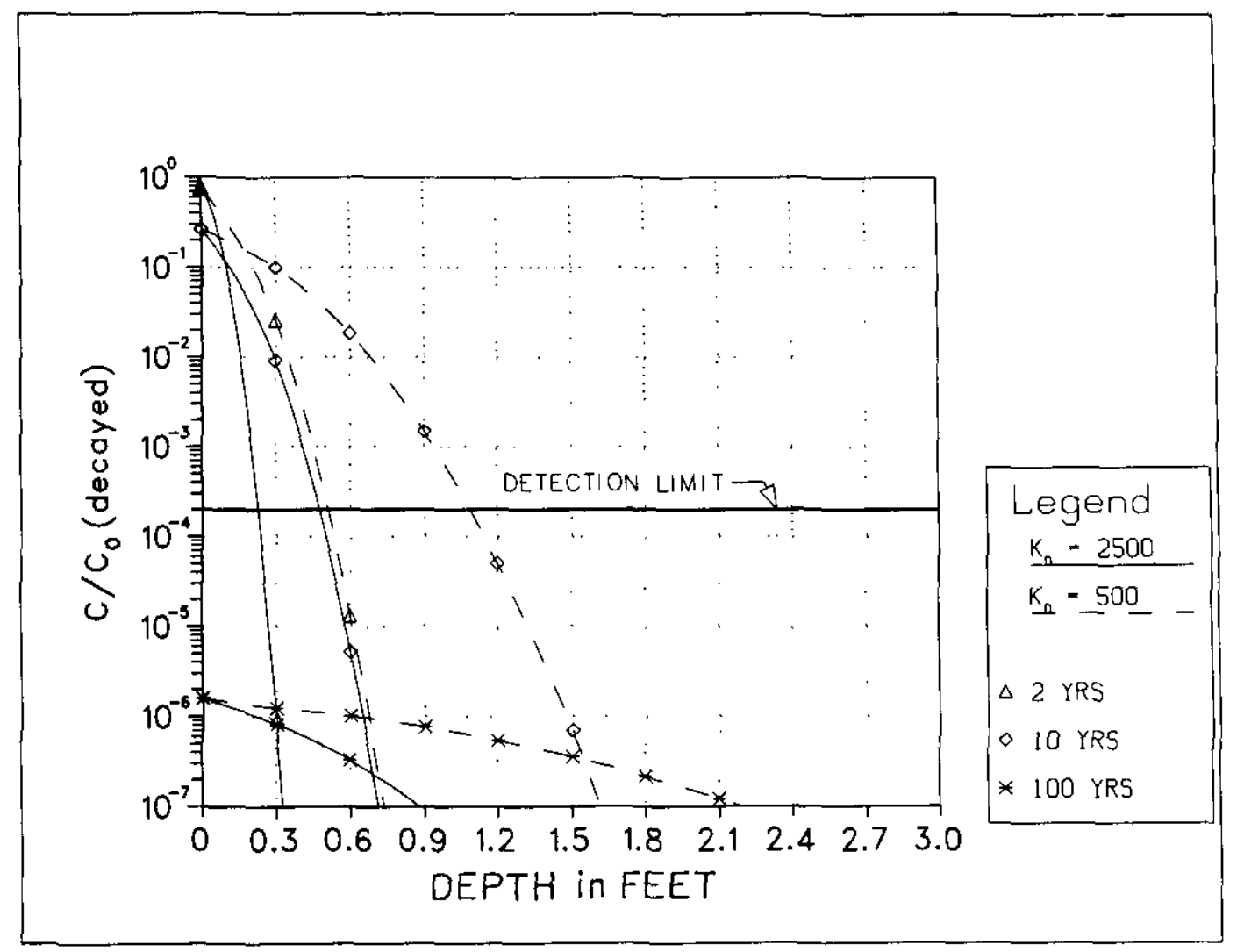

FIGURE 13. Cobalt-60 in Soil Water vs. Deptl in Soil 


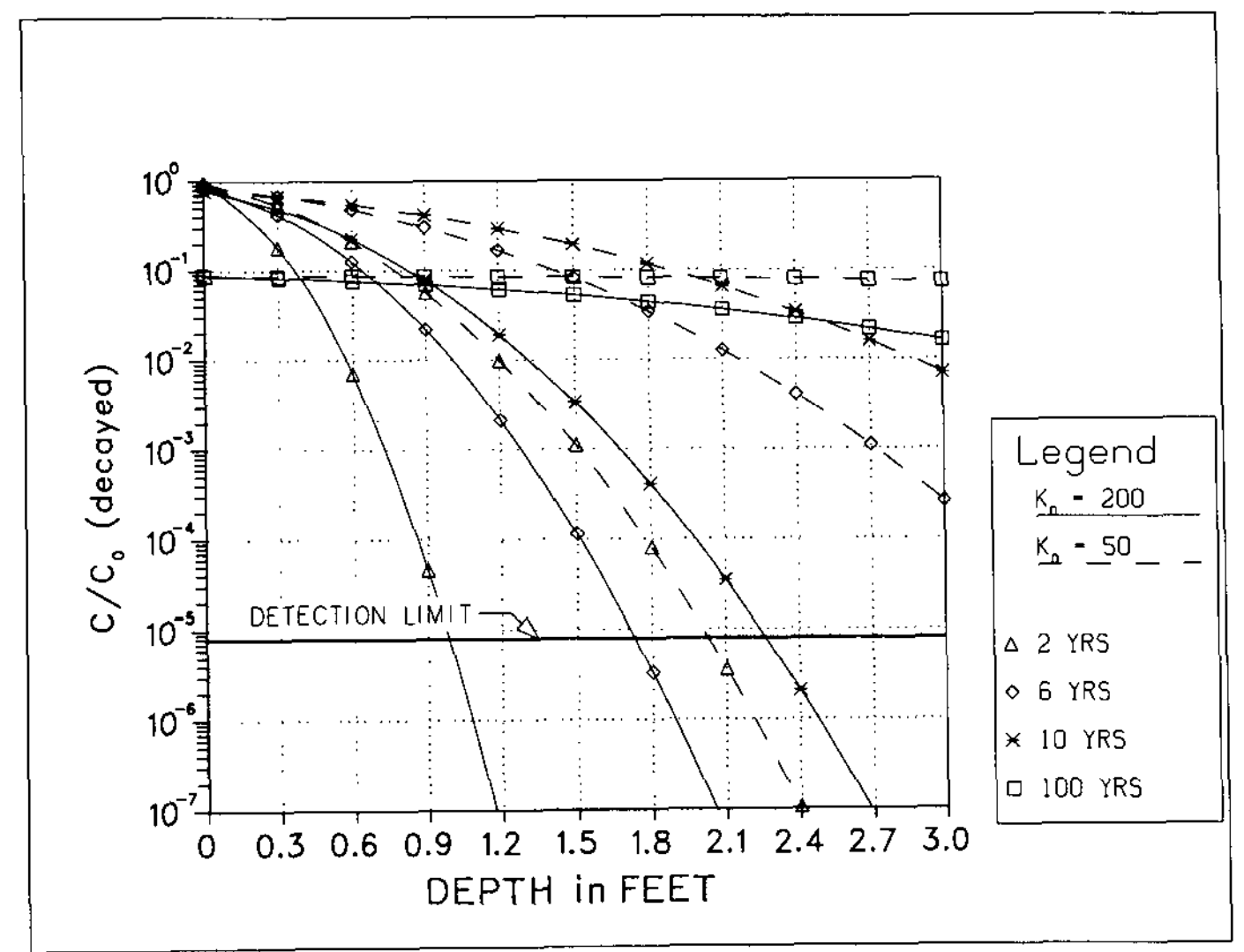

FIGURE 14. Strontium-90 in Soll Water vs. Depth in Soil 


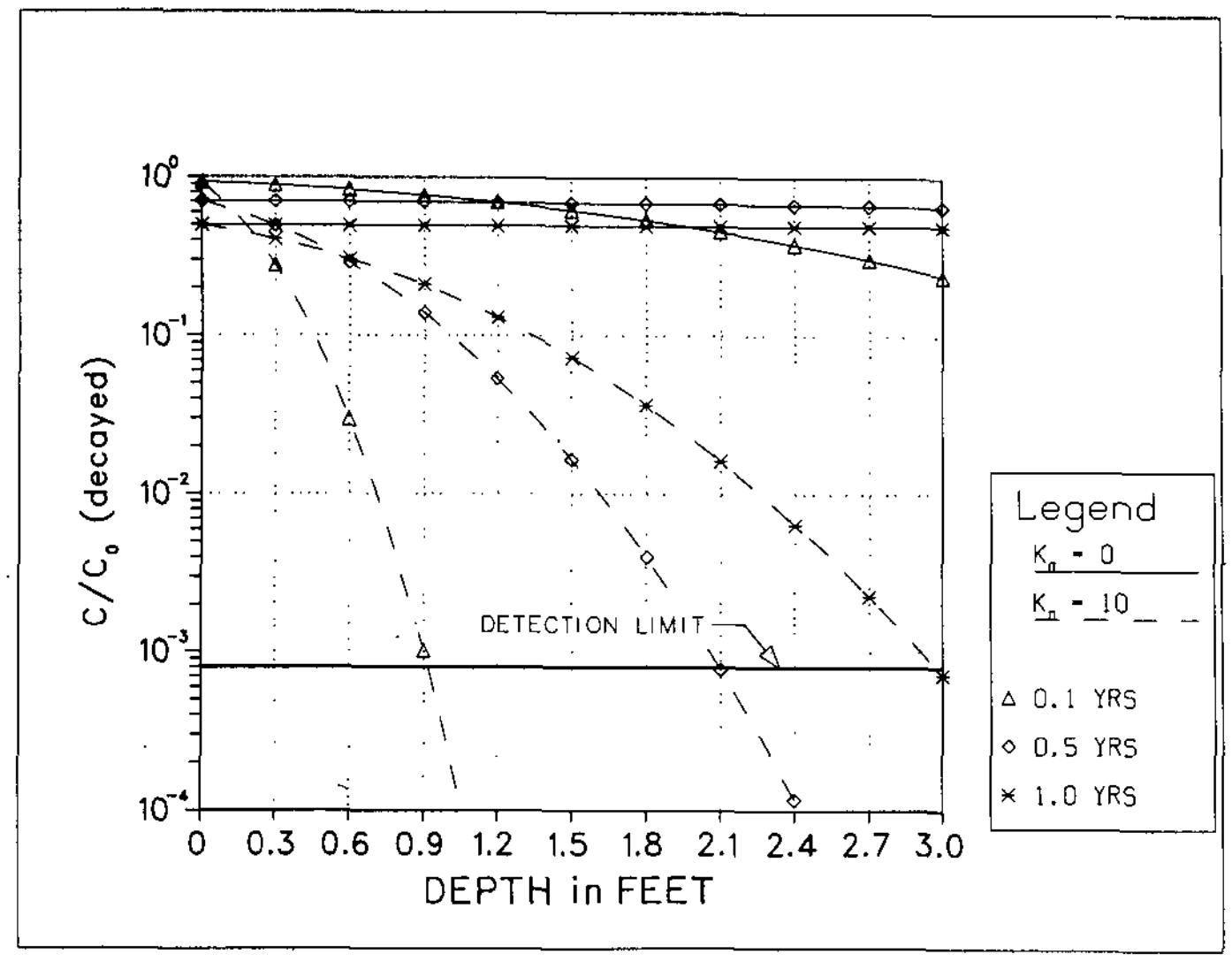

FIGURE 15. Ruthenium-106 in Soil Water vs. Depth in So11 


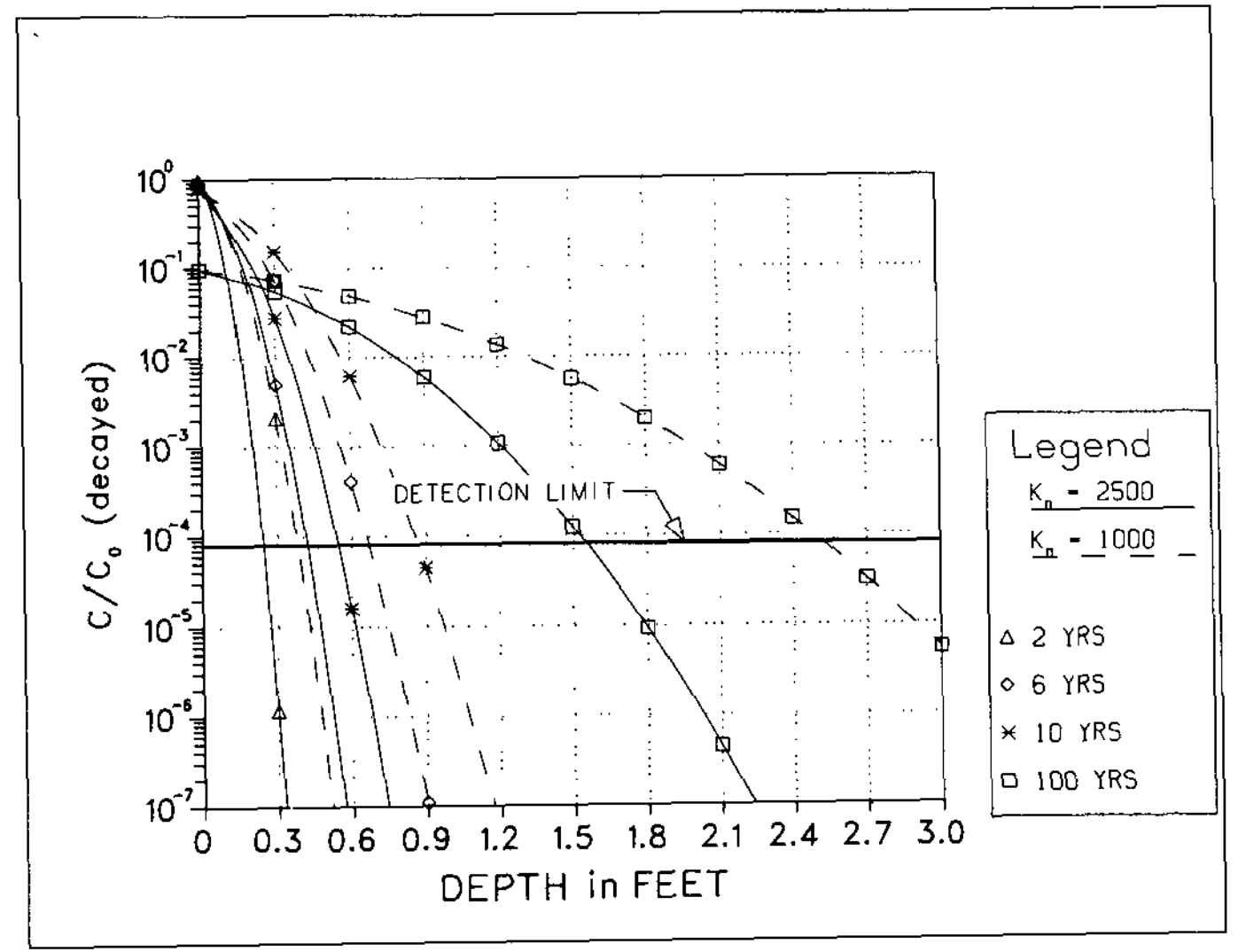

FIGURE 16. Cesium-137 in Soil Water vs. Depth in Soil 


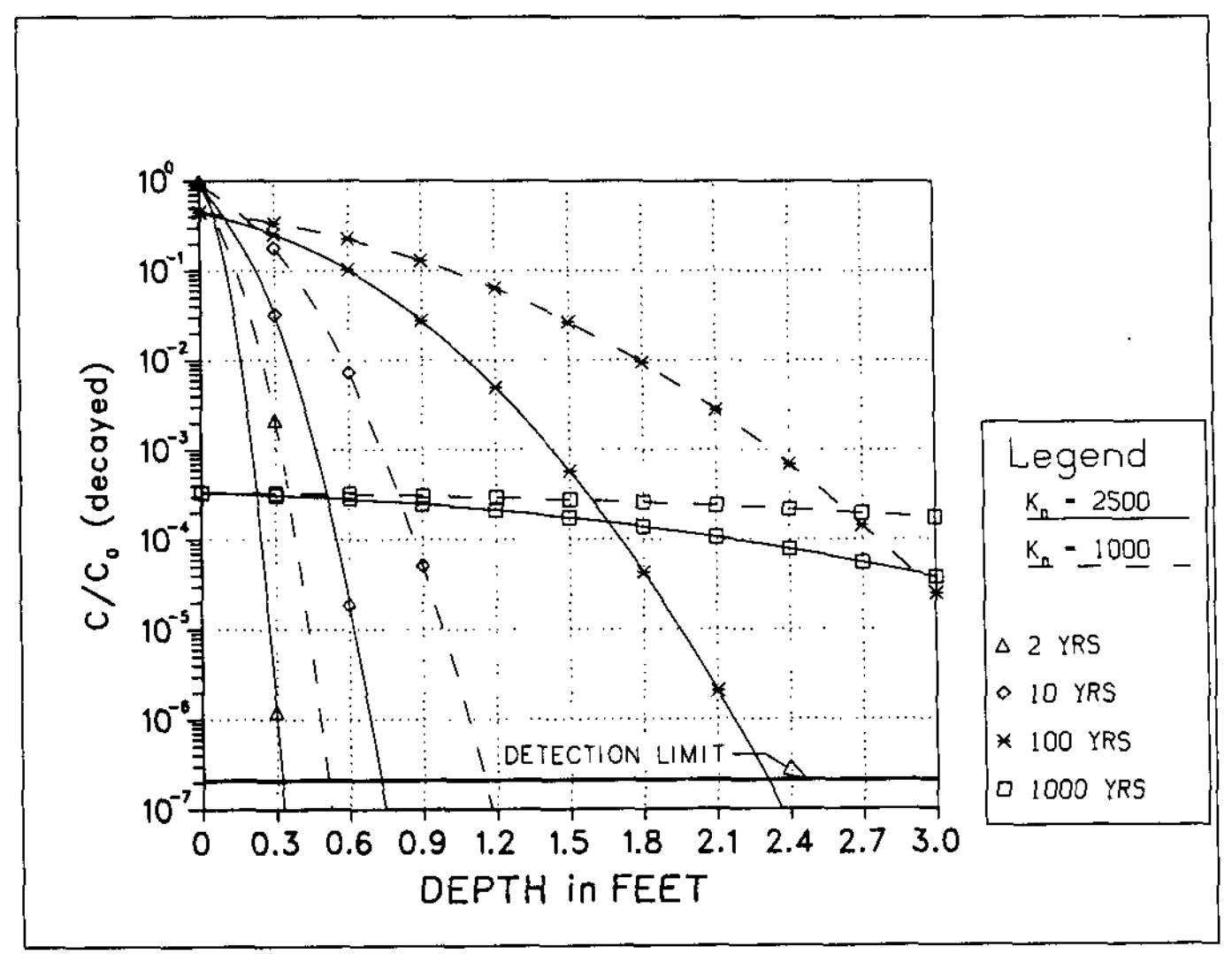

FIGURE 17. Plutonlum-238 in Soil Water vs. Depth in Soil 


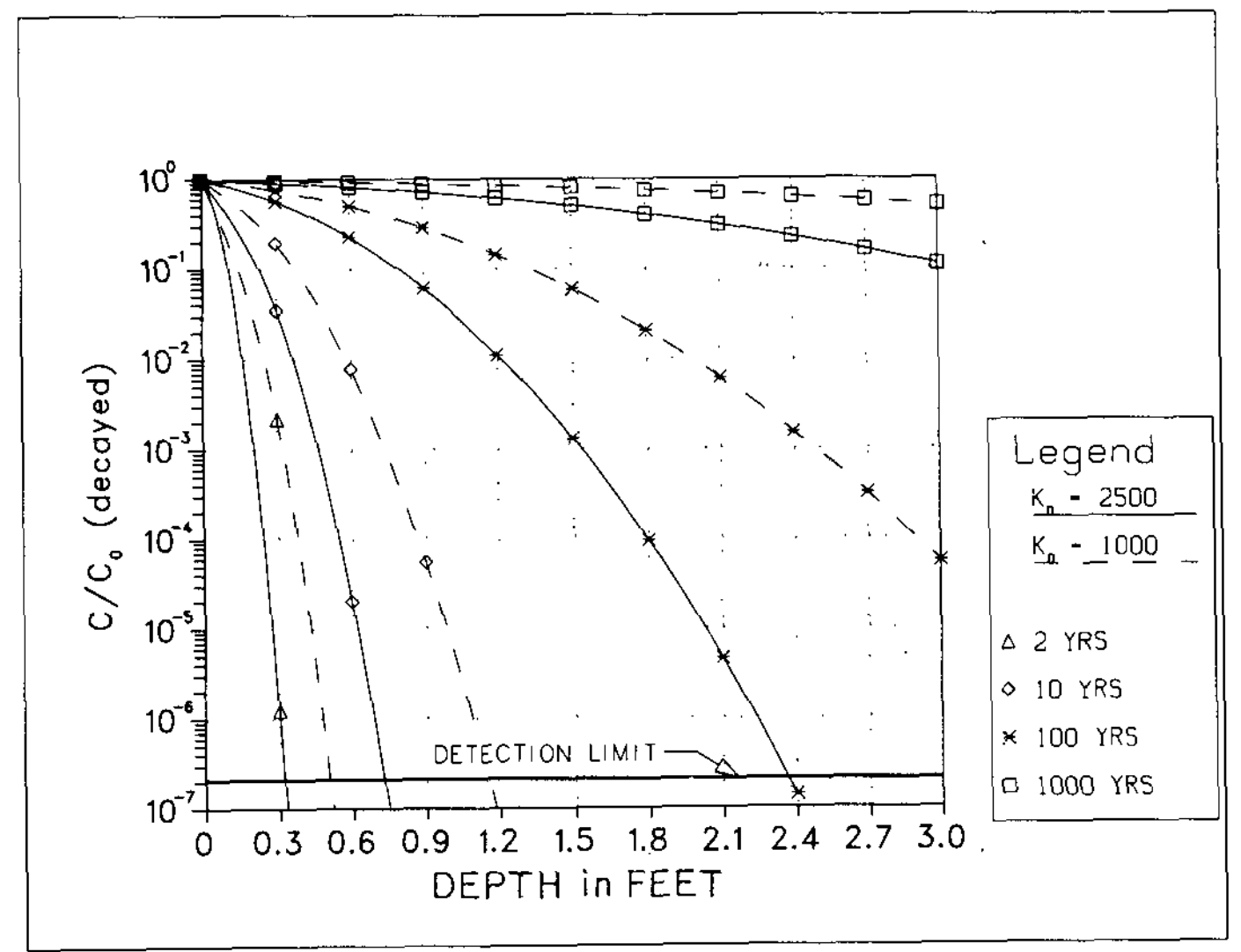

FIGURE 18. Plutonium-239 in Soil Water vs. Depth in Soil 


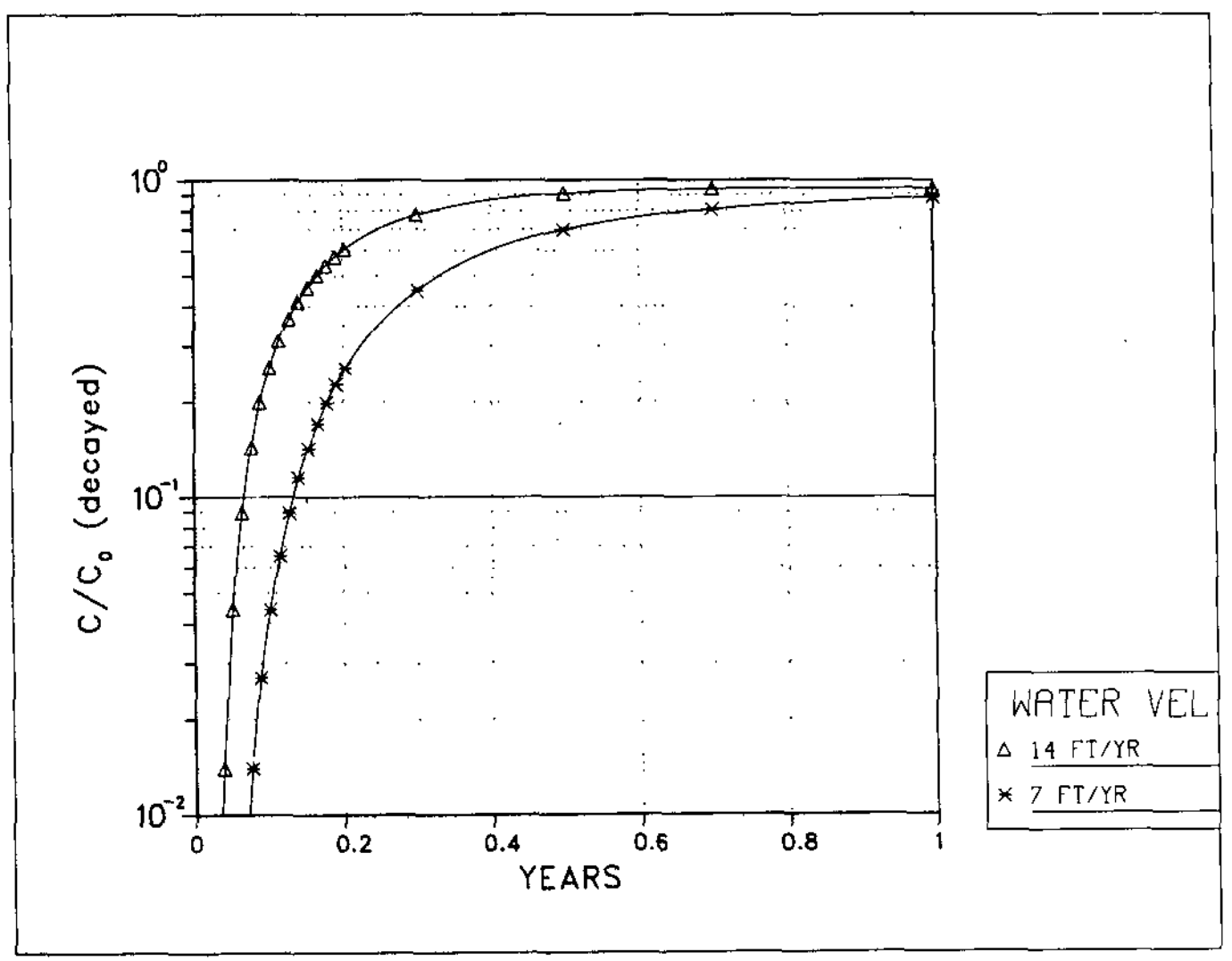

FIGURE 19. Tritium in Soil Water vs. Time (at bottom of Lysimeter) 


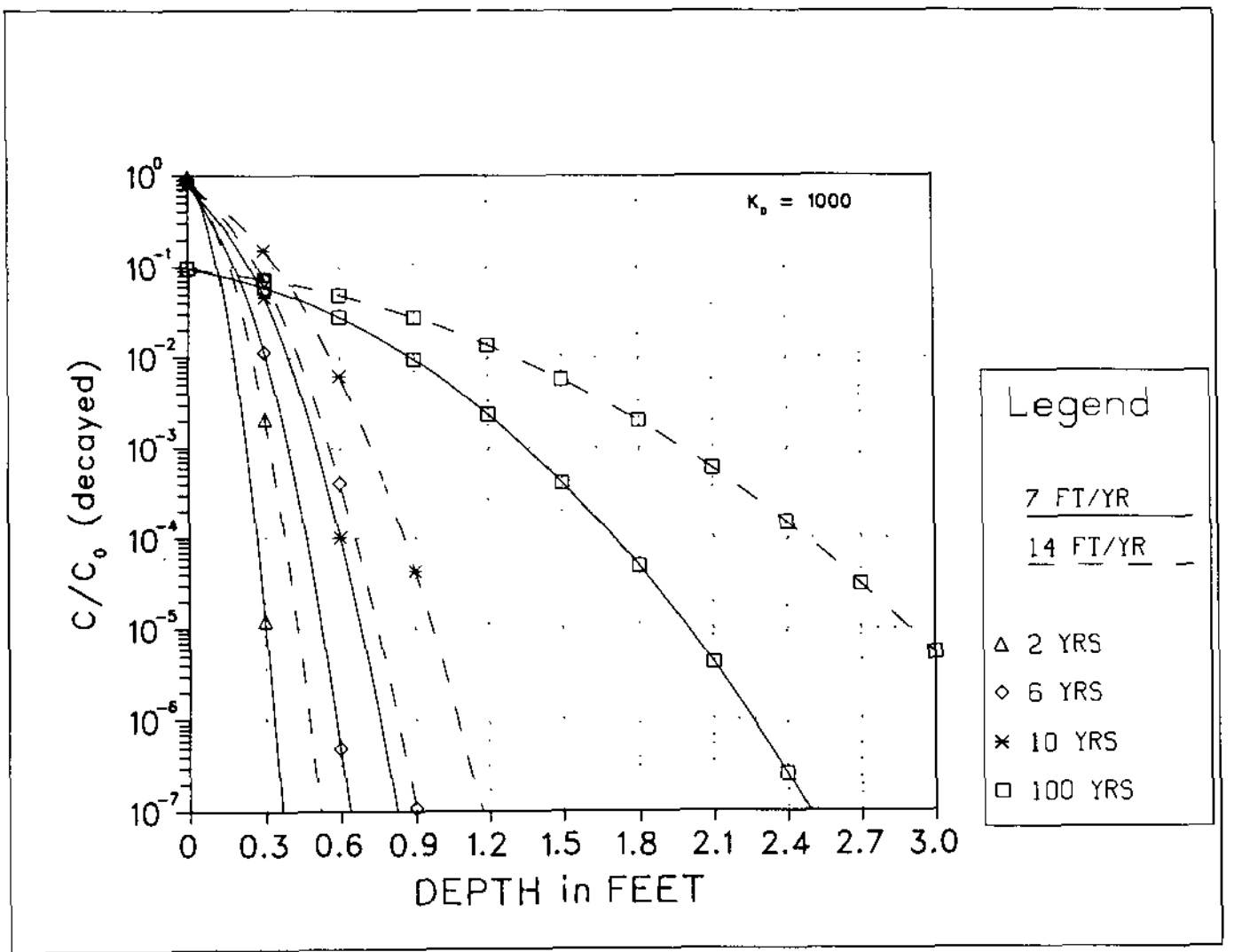

FIGURE 20. Cesium-137 in Soil Water vs. Depth in Soil (effect of Water Velocity) 
TABLE 2

Estimated Minimum $\mathrm{C} / \mathrm{C}_{\mathrm{o}}$ for Detection of Radioisotopes

\begin{tabular}{|c|c|c|c|c|c|}
\hline Radioisotope & $\begin{array}{l}\text { Ci per } \\
\text { Lysimeter } \\
\text { (basis for } \\
\text { calculation) }\end{array}$ & $\begin{array}{l}\text { Assumed } \\
\text { Fraction } \\
\text { Leached, } \\
\% / y r\end{array}$ & $\begin{array}{l}\text { Calculated } \\
\mathrm{C}_{\mathrm{o}}, \mathrm{pCi} / \mathrm{mL}^{\mathrm{a}}\end{array}$ & $\begin{array}{l}\text { Detection } \\
\text { Limited, } \\
\mathrm{pCi} / \mathrm{mL}^{\mathrm{b}} \\
\end{array}$ & $\begin{array}{l}\mathrm{C} / \mathrm{C}_{\mathrm{o}}(\min \\
\text { detectable }) \\
\end{array}$ \\
\hline $238, \quad 239 \mathrm{Pu}$ & 0.2 & 1 & 950 & $2 \times 10^{-4}$ & $2 \times 10^{-7}$ \\
\hline${ }^{137} \mathrm{Cs}$ & 0.1 & 5 & 2380 & 0.2 & $8 \times 10^{-5}$ \\
\hline${ }^{90} \mathrm{Sr}$ & 0.1 & 5 & 2380 & 0.02 & $8 \times 10^{-6}$ \\
\hline${ }^{60} \mathrm{Co}$ & 0.2 & 1 & 950 & 0.2 & $2 \times 10^{-4}$ \\
\hline${ }^{106} \mathrm{Ru}$ & 0.1 & 5 & 2380 & 2 & $8 \times 10^{-4}$ \\
\hline
\end{tabular}

a Basis: 31 in./yr rainfall infiltration.

b Sample size $=500 \mathrm{~mL}$.

c For 6-ft diameter lysimeters. For 10-ft diameter lysimeters multiply $l$ isted $c / C_{o}$ values by 3 . 
Since the rainfall is known, if one assumes a leach rate, a value for $\mathrm{C}_{\mathrm{O}}$ can be calculated. Table 2 gives $\mathrm{C}_{\mathrm{O}}$ values based on assumed leach rates and also provides the minimum concentration of the given radionuclide which can be readily detected in water samples. Based on the rainfall and assumed leach rates, the $c / C_{O}$ values corresponding to this minimum detectable concentration were determined and are shown as a line on the plots of Figures 13 through 18. Theoretically, any $\mathrm{C} / \mathrm{C}_{\mathrm{o}}$ value above this line can be readily detected by standard analytical techniques.

Migration of ${ }^{137} \mathrm{Cs}$ at water velocities of $7 \mathrm{ft} / \mathrm{yr}$ and 14 $\mathrm{ft} / \mathrm{yr}$ were calculated (Figure 20). The velocity of $7 \mathrm{ft} / \mathrm{yr}$ approximates the infiltration rate of water in the unsaturated zone in the burial ground (with run-off) and also approximates the saturated zone flow rate in the lysimeters. The effect of water velocity is observed by noting that after 100 years the $c / C_{0}$ ratio is $10^{-4}$ at the $1.7-\mathrm{ft}$ depth with a $V_{w}$ of $7 \mathrm{ft} / \mathrm{yr}$, but this same concentration is reached at a depth of $2.5 \mathrm{ft}$ after 100 years with a $v_{w}$ of $14 \mathrm{ft} / \mathrm{yr}$. This comparison also represents the approximate difference in migration between the unsaturated (14 ft/yr) and saturated zones $(7 \mathrm{ft} / \mathrm{yr})$ of the lysimeters.

The influence of leaching was neglected in the foregoing plots, as mentioned earlier. However, the transport equation provides for depletion of the source by leaching. (The term $\gamma$ is the decay constant for the source, considering all mechanisms.) To investigate the effect of depletion of the source by leaching, the distribution of ${ }^{239} \mathrm{Pu}$ in soil water was calculated assuming $1 \%$ per year leaching (Figure 21 ). The case for no depletion of the source by leaching is also shown. The initial concentration (at time $=0$ ) was assumed to be the same for both cases. Concentrations are presented in absolute units based on the $1 \%$ leach rate and the average rainfall (Table 2). The results show that leaching and decay reduces the source concentration by a factor of about 0.33 after 100 years, but by a much smaller factor $\left(3.6 \times 10^{-5}\right)$ after 1000 years. However, because of the slow rate of movement of ${ }^{239} \mathrm{Pu}$ through soil, the effect is only a factor of about 4 at the $3-f t$ depth after 1000 years.

\section{Recommendations for Field Tests}

This study suggests that data from the lysimeters may be used in the following way to determine important parameters of migration:

D - The dispersion coefficient for local soils could be measured by introducing a nonadsorbing species (e.g. HTO or $\mathrm{T}_{2} \mathrm{O}$ ) to a new (or existing) lysimeter and observing the effluent concentration. With $\mathrm{K}_{\mathrm{d}}=0$ and $\mathrm{C}_{\mathrm{O}}$ known, $\mathrm{D}$ could be determined by substituting values into the equation to determine which value best fits the data. 


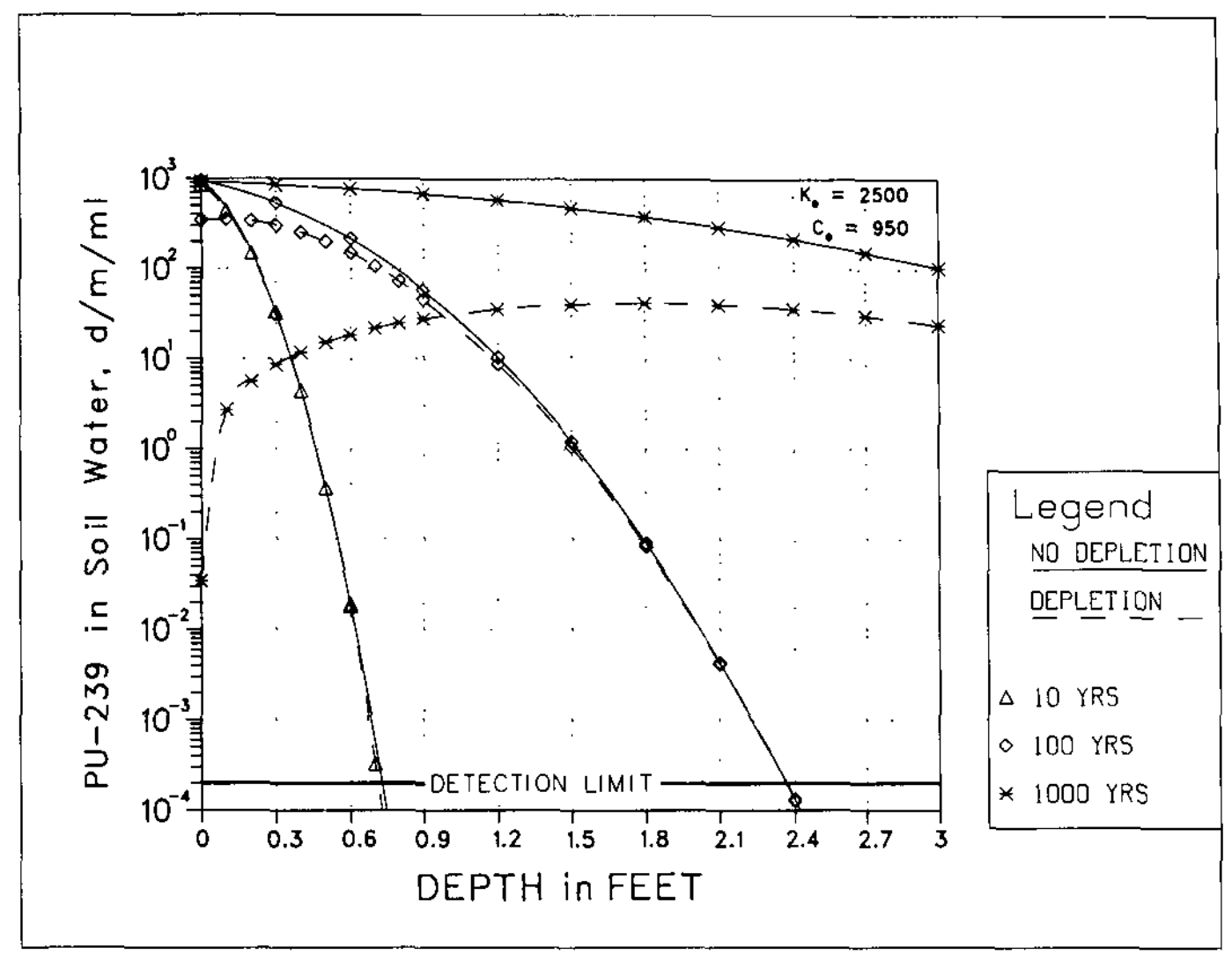

FIGURE 21. Plutonium-239 in Soil Water vs. Depth in Soil (effect of source depletion) 
$K_{d}$ - $K_{d}$ values could be determined (assuming $D$ is known) by substituting various $\mathrm{K}_{\mathrm{d}}$ values into the transport equation until the best agreement was found between calculated and measured lysimeter effluent data. Figure 22 shows ca1culated effluent data for $106_{\text {Ru }}$ plotted vs.time, holding $D$ constant. The slope and shape of the curves show a strong dependence on $\mathrm{K}_{\mathrm{d}}$. For isotopes which are not detectable in the lysimeter sump water, soil moisture samples taken at different times at a single depth would provide similar information. One could also sample soil moisture at various depths at a given time and insert the radionuclide concentrations into the transport equation and solve for $K_{d}$.

$\mathrm{C}_{\mathrm{O}}$ - (or leaching) $-\mathrm{C}_{\mathrm{o}}$ becomes known when one establishes the $\mathrm{C} / \mathrm{C}_{\mathrm{o}}$ vs.depth relationship (by determining $\mathrm{K}_{\mathrm{d}}$ and $\mathrm{D}$ ) and also obtains an actual concentration value for a specific case.

The foregoing discussion illustrates the type of calculations which $c$ an be made and identifies important parameters. The calculations presented are based on ranges of some parameters and estimates of others. However, the information given should provide guidance for directing further studies and for anticipating lysimeter performance until improved input values are obtained.

\section{CONCLUSIONS}

The assessment of potential long-term hazards from buried radioactive wastes is important in making good decisions about the future disposition of burial grounds. The lysimeter studies described in this report are designed to provide improved radionuclide migration data for these assessments. Results from the studies will also be useful in guiding ongoing burial ground operations. The work should be carried out as planned and perhaps amplified as results become available and as future plant operations change.

The need for additional work to define some of the parameters which influence radionuclide migration is emphasized. This work should consider the unsaturated and the saturated zone. Soil used in any experiments should be well characterized. Parameters which need further study are:

- $\mathrm{K}_{\mathrm{d}}$ (distribution coefficient) - needed for various radionuclides and various soil types. 


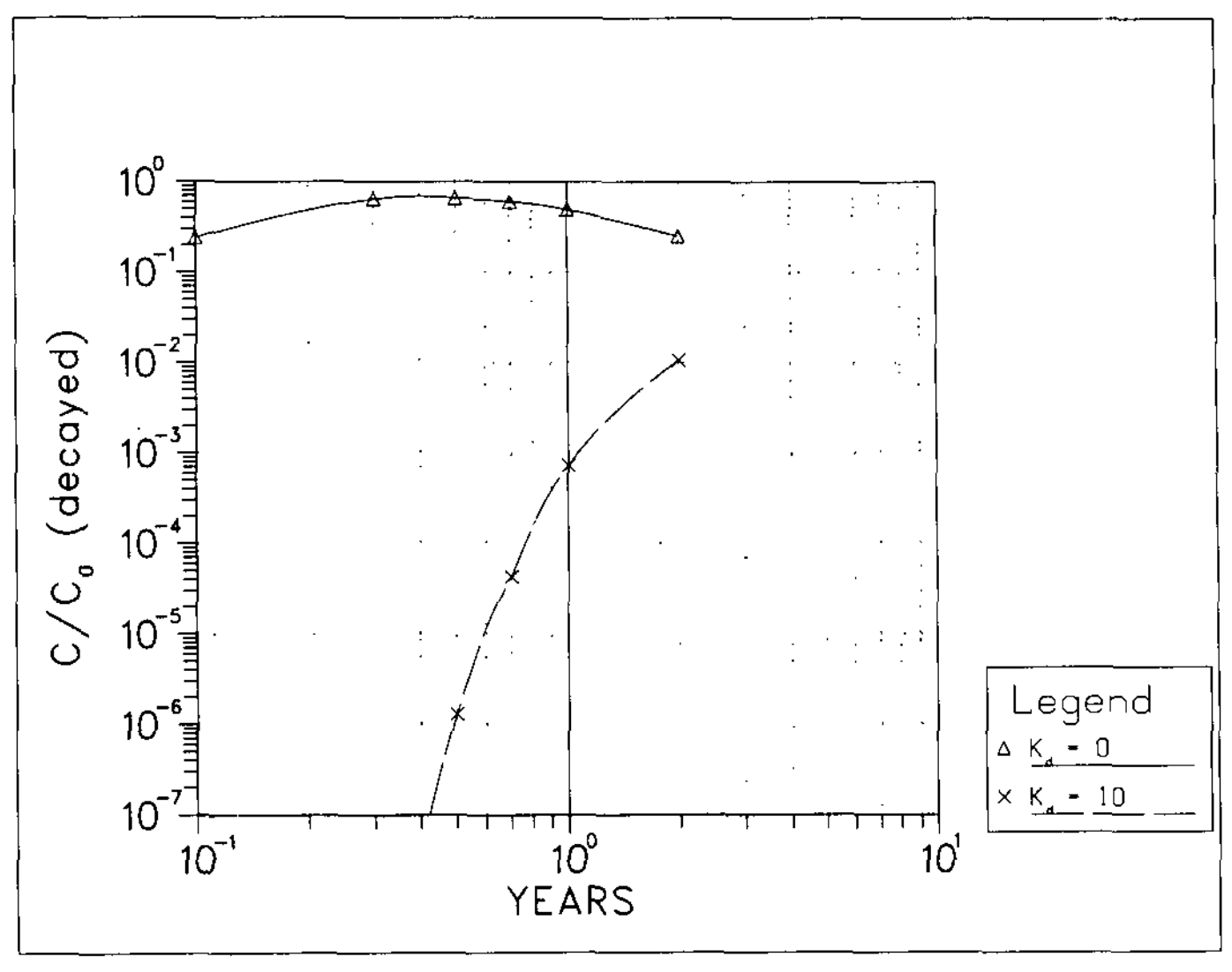

FIGURE 22. Ruthenium-106 in Sump Water (effect of $\mathrm{K}_{\mathrm{d}}$ ) 
- D (dispersion coefficient) - this parameter has a strong influence on migration, yet very 1 ittle is known about it for local soil types.

- $V_{w}$ (groundwater velocity) - including the effect of the intermittent nature of rainfall on radionuclide migration.

\section{ACKNOWLEDGMENTS}

The authors wish to acknowledge the substantial contributions by R. H. Hawkins and J. H. Horton in designing and setting up the lysimeter tests, and to various Savannah River Plant and Laboratory personnel for contributions in procuring, measuring, and installing the waste forms. 


\section{REFERENCES}

1. J. H. Horton and J. C. Corey. Storing Solid Radioactive Wastes at the Savannah River Plant. USERDA Report DP-1366, E. I. du Pont de Nemours \& Co., Savannah River Laboratory, Aiken, SC (1976).

2. J. W. Fenimore and R. L. Hooker. The Assessment of Solid Low-Leve1 Waste Management at the Savannah River Plant. USERDA Report DPST-77-300, E. I. du Pont de Nemours \& Co., Savannah River Laboratory (1977).

3. R. H. Hawkins. "Migration of Tritium from a Nuclear Burial Site." USERDA Report CONF-750967, Proc. Third ERDA Environmental Protection Conference, Chicago (1975).

4. J. Bear. Dynamics of Fluids in Porous Media, American Elsevier Publishing Co., New York, NY (1972).

5. R. W. Cleary. Groundwater Pollution and Hydrology: Mathematical Model and Computer Programs. Cont inuing Engineering Education Course Notes, Princeton University (1977).

6. J. N. Lucas. "The Transport of a Radioactive Salt Through a Semi-Infinite Column of Porous Medium: A Physical Mode1." Water Resources Research, 16 (2) 387-390 (1980).

7. S. P. Gupfa and R. A. Greenhorn. "Determination of Dispersion and Nonlinear Absorption Parameter for Flow in Porous Media." Water Resources Research, 10 (4) 839-846 (1974).

8. J. H. Horton. Soil Moisture Flow as Related to the Burial of Solid Radioactive Wastes. USAEC Report DPST-75-218, E. I. du Pont de Nemours \& Co., Savannah River Laboratory (1975).

9. J. E. Hoy. Evaluation of a Gamma Monitor for Survey of Waste for Shallow Land Buria1. USDOE Report DP-1519, E. I. du Pont de Nemours \& Co., Savannah River Laboratory (1978). 
1 " i

t. it.

i.

*

APPENDIX 
TABLE A-1

\section{Comprehensive Lysieter Loading Dat}

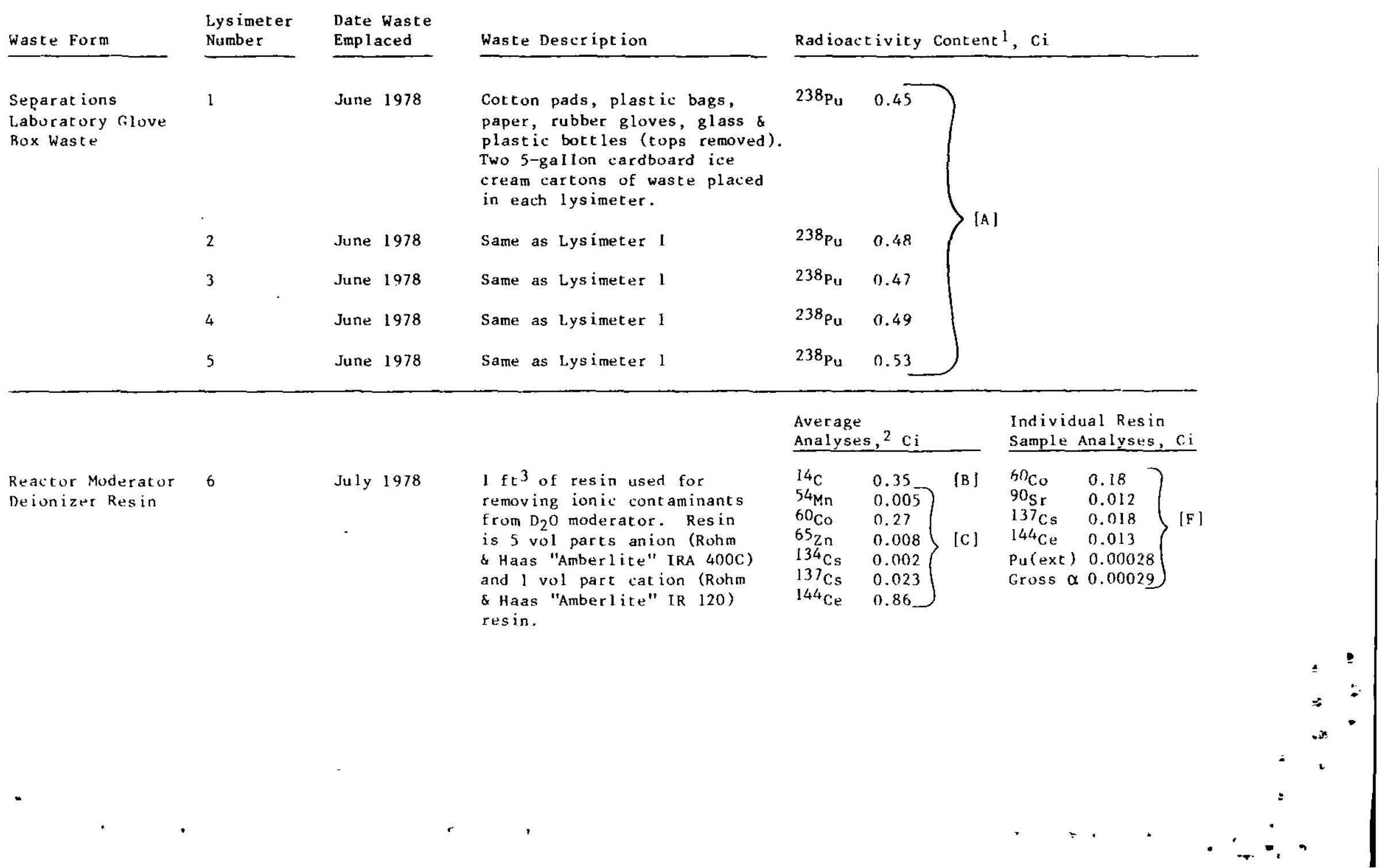


TABLE A-1, Contd

Waste Form

Reactor Moderator

Deionizer Res in
Lys imeter

Number

7
Date Waste Emplaced

July 1978

Same as Lysimerer 6

Same as Lysimeter 6

Waste Description

\begin{tabular}{ll} 
Average & Individual Resin \\
Analyses, ${ }^{2} \mathrm{Ci}$ & Sample Analyses, Ci \\
\hline
\end{tabular}

$60 \mathrm{Co} \quad 0.17$

${ }^{90} \mathrm{Sr} \quad 0.011$

$137 \mathrm{Cs} \quad 0.016$

$144 \mathrm{Ce} \quad 0.012$

Pu(ext) 0.00014

Gross $\alpha 0.00029$

July 1978

Same as Lysimeter 6

Same as Lysimeter 6

$60 \mathrm{C}$

$90 \mathrm{Co} \quad 0.12$

$\begin{array}{ll}90 \mathrm{SI} & 0.0069\end{array}$

$137 \mathrm{Cs} \quad 0.016$

$144 \mathrm{Ce} \quad 0.011$

$\mathrm{Pu}(\mathrm{ext}) \quad 0.00036$

Gross $\alpha 0.00037$

July 1978

Same as Lysimeter 6

Same as Lysimeter 6

$60 \mathrm{Co} \quad 0.086$

$9^{90} \mathrm{Sr} \quad 0.0063$

$137 \mathrm{Cs} \quad 0.011$

${ }^{144} \mathrm{Ce} \quad 0.0076$

$\mathrm{Pu}$ (ext) 0.00020

Gross $\alpha 0.00028$
Same as Lys imeter 6
Same as Lysimter 6

$\left.\begin{array}{ll}54 \mathrm{Mn} & 0.0011 \\ 57 \mathrm{Co} & 0.00061 \\ 60 \mathrm{Co} & 0.10 \\ 90 \mathrm{Sr} & 0.0031 \\ 137 \mathrm{Cs} & 0.015 \\ 144 \mathrm{Ce} & 0.0052 \\ \mathrm{Pu}(\mathrm{ext}) & 0.000083 \\ \mathrm{Gross} & 0.00015\end{array}\right\}[\mathrm{F}]$

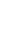




\section{TABLE A-1, Contd}

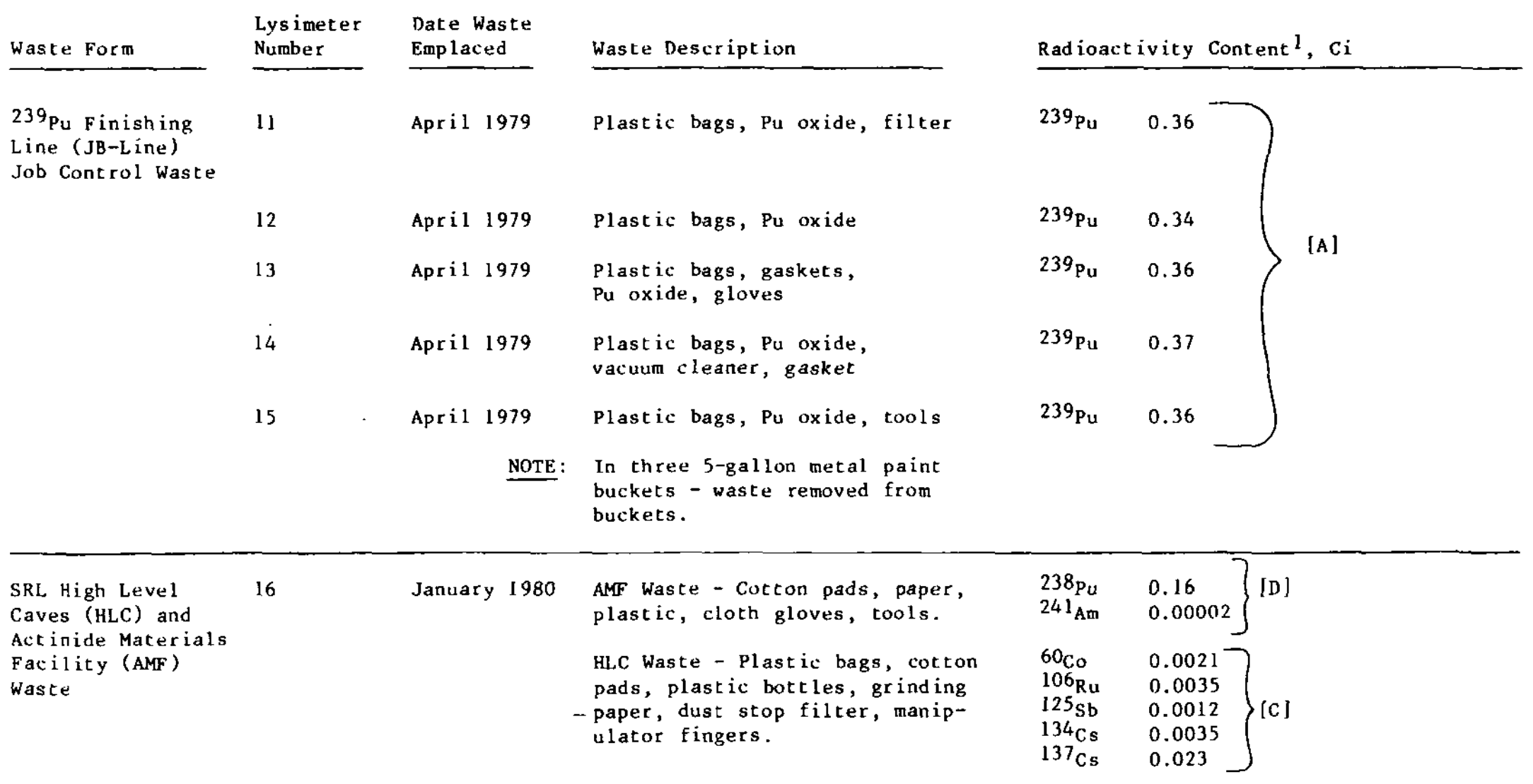


TABLE A-1, Contd

\section{Waste Form}

SRL High Leve1

Caves (HLC) and

Actinide Materials

Facility (AMF)

Waste (Cont'd)

\section{Lys imeter \\ Number}

17
Date Waste

Emplaced

February 1980

AMF Waste - Same as

Lysimeter 16

HLC Waste-Assorted plastic bags cotton pads, sample vials and caps, metal knife, plastic bottles, $\mathrm{Zr}$ powder

January 1980

AMF Waste-Plastic bags, cotton pads

HLC Waste-Plastic bags, cotton pads, used centrifuge cover,

broken glass bottles, poly-

ethylene bottles, broken manipulator hand.

AMF Waste-plastic bags, cotton pads, glassware

HLC Waste-Dust stop filter, plastic bags, cotton wipes, polishing cluths
Radioactivity Content ${ }^{1}, \mathrm{Ci}$

$\left.\begin{array}{ll}238_{\mathrm{Pu}} & 0.16 \\ 241_{\text {Am }} & 0.0007 \mathrm{Ci}\end{array}\right\}[D]$

$\left.\begin{array}{ll}106_{\mathrm{Ru}} & 0.026 \\ 134 \mathrm{Cs} & 0.027 \\ 137 \mathrm{Cs} & 0.163\end{array}\right\}[\mathrm{Cl}$

$\left.\begin{array}{ll}238 \mathrm{Pu} & 0.14 \\ 241 \mathrm{Am} & 0.000015\end{array}\right\}[\mathrm{D} \mid$

$\left.\begin{array}{ll}22 \mathrm{Na} & 0.00005 \\ 60 \mathrm{Co} & 0.00022 \\ 103 & 0.078 \\ 106 \mathrm{Ru} & 0.037 \\ 125 \mathrm{Sb} & 0.0043 \\ 134 \mathrm{Cs} & 0.0063 \\ 137 \mathrm{Cs} & 0.037 \\ 154 \mathrm{Eu} & 0.0016\end{array}\right)^{\mathrm{Cu}}$

$\left.\begin{array}{ll}238 & \\ 241 & 0.16 \\ \mathrm{Am} & 0.000032\end{array}\right\}[\mathrm{D}]$

${ }^{60} \mathrm{Co} \quad 0.0010$

$106 \mathrm{Ru} \quad 0.00060$

${ }^{134} \mathrm{Cs} \quad 0.00026$

$137 \mathrm{Cs} \quad 0.00165$

$\begin{array}{ll}144 \mathrm{Ce} & 0.00090\end{array}$ 
TABLE A-1, Contd

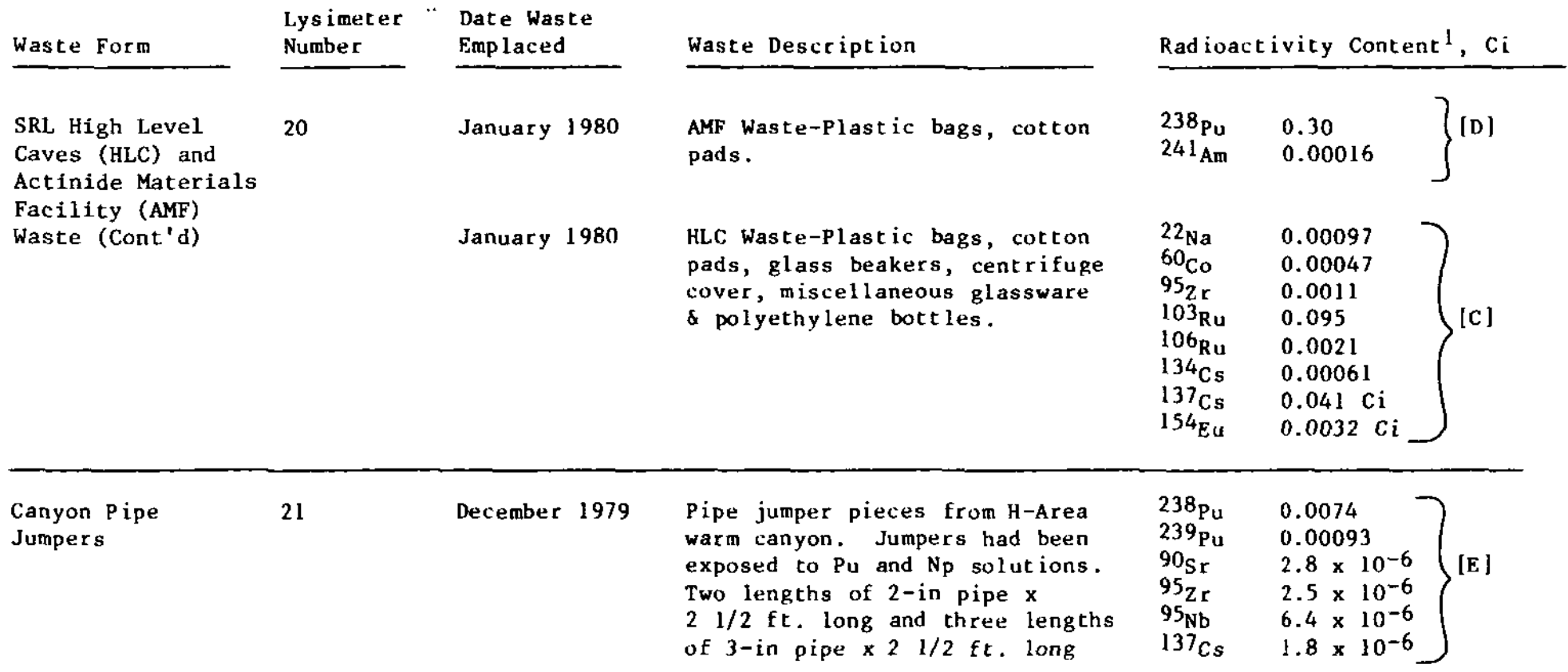

$22,23,24,25 \quad$ December 1979 Each same as Lysimeter $21 \quad$ Each same as Lysimeter 21

\begin{tabular}{|c|c|c|c|c|c|}
\hline $\begin{array}{l}\text { Separations } \\
\text { Laboratory } \\
\text { Waste }\end{array}$ & 26 & August 1979 & $\begin{array}{l}\text { Glass sample vials, vial caps, } \\
\text { burette and pipette tips, cotton } \\
\text { pads and plastic containers. One } \\
5-g a l l o n \text { cardboard ice cream } \\
\text { carton containing three } 2 \text { quart } \\
\text { cardboard cartons per lysimeter. }\end{array}$ & $\begin{array}{l}95 \mathrm{Zr} \\
95_{\mathrm{Nb}} \\
106_{\mathrm{Ru}} \\
134 \mathrm{Cs} \\
137 \mathrm{Cs} \\
144 \mathrm{Ce}\end{array}$ & $\begin{array}{l}0.0077 \\
0.011 \\
0.012 \\
0.0017 \\
0.0054 \\
0.050\end{array}$ \\
\hline
\end{tabular}

lysimeter. 
TABLE A-1, Contd

\section{Waste \\ Form}

Separations

Laboratory Waste
Lys imeter Number

27

(1)

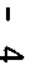

Date Waste

Enplaced

August 1979

Waste Description

Same as Lysimeter 26

(a)

August 1979

Same as Lysimeter 26

August 1979
August 1979
Same as Lysimeter 26
Radioactivity Content ${ }^{1}, \mathrm{Ci}$

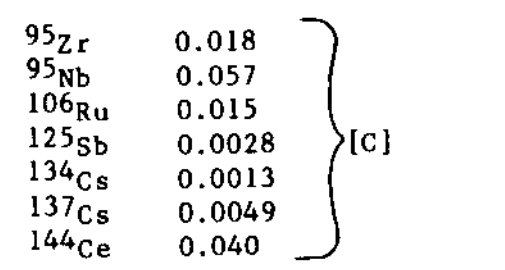

95

$95 \mathrm{Zr} \quad 0.021$

$95 \mathrm{Nb} \quad 0.022$

$106_{\mathrm{Ru}} \quad 0.0020$

${ }_{134} \mathrm{Cs} \quad 0.0028$

${ }^{137} \mathrm{Cs} \quad 0.0085$

$144 \mathrm{Ce} \quad 0.078$

$2 \mathrm{r} \quad 0.0060$

$103 \mathrm{Ru} \quad 0.00091$

$106_{\mathrm{Ru}} \quad 0.014$

$134 \mathrm{Cs} \quad 0.00099$

$137 \mathrm{Cs} \quad 0.0043$

$144 \mathrm{Ce} \quad 0.040$

${ }^{95} \mathrm{Zr} \quad 0.0052$

$95 \mathrm{r} \quad 0.0052$

$95_{\mathrm{Nb}} \quad 0.0084$

${ }_{106} \mathrm{Ru} \quad 0.0087$

$134 \mathrm{Cs} \quad 0.0011$

$137 \mathrm{Cs} \quad 0.0037$

$144 \mathrm{Ce} \quad 0.035$ 
Table A-1, Contd

\section{Waste \\ For m}

Separat ions

Canyon Job

Control Waste

$\stackrel{\leftrightarrow}{\infty}$

Lysimeter Date Waste

Number

31

Emplace

May 1979

Plastic suits, cotton coveralls, rubber gloves and over shoes \& cotton pads. Three 15"x15"x15" cardboard boxes of waste were

placed in each lysimeter. Boxes were opened in lysimeter.

May 1979

May 1979
May 1979
Same as Lysimeter 31

Waste Description

Same as Lysimeter 31

Same as Lysimeter 31

Same as Lysimeter 31
Radioactivity Content ${ }^{1}, \mathrm{Ci}$

$\left.\begin{array}{ll}952 \mathrm{r} & 0.11 \\ 95_{\mathrm{Nb}} & 0.17 \\ 106_{\mathrm{Ru}} & 0.09 \\ 137 \mathrm{Cs} & 0.16 \\ 144 \mathrm{Ce} & 0.38\end{array}\right\}[\mathrm{C}]$

$\left.\begin{array}{ll}95 \mathrm{Zr} & 0.28 \\ 95_{\mathrm{Nb}} & 0.27 \\ 103_{\mathrm{Ru}} & 0.24 \\ 106_{\mathrm{Ru}} & 0.29 \\ 137 \mathrm{Cs} & 0.21 \\ 144 \mathrm{Ce} & 0.65\end{array}\right\}[\mathrm{C}]$

$95_{\mathrm{Z}}$

$95 \mathrm{~N}$

$106_{\mathrm{Ru}}$

$137 \mathrm{C}$

0.16

0.21

0.28

0.15

0.29

$952 \mathrm{r}$

$95 \mathrm{Zr} \quad 0.10$

$95 \mathrm{Nb}$

0.13
0.19

$137 \mathrm{Cs}$

$144 \mathrm{Ce}$

0.16
0.28

$95 \mathrm{Zr} \quad 0.09$

$95 \mathrm{~N}$

$106_{\mathrm{R}}$

$125 \mathrm{~S}$

$144 \mathrm{Ce}$

0.14

0.15

0.04

0.14
0.37 
Table A-1, Contd

\begin{tabular}{|c|c|c|c|}
\hline $\begin{array}{l}\text { Waste } \\
\text { Form }\end{array}$ & $\begin{array}{l}\text { Lys imeter } \\
\text { Number }\end{array}$ & $\begin{array}{l}\text { Date Waste } \\
\text { Emplaced }\end{array}$ & Waste Description \\
\hline \multirow[t]{5}{*}{$\begin{array}{l}\text { Reactor Scrap } \\
\text { Metal }\end{array}$} & 36 & March 1978 & $\begin{array}{l}\text { Reactor scrap metal }{ }^{3} \text { consisting } \\
\text { of cut-up aluminum fuel housings } \\
\text { and stainless steel snap rings }\end{array}$ \\
\hline & 37 & March 1978 & Same as Lysimeter 36 \\
\hline & 38 & March 1978 & Same as Lysimeter 36 \\
\hline & 39 & March 1978 & Sames as Lysimeter 36 \\
\hline & 40 & June 1979 & Same as Lysimeter 36 \\
\hline
\end{tabular}

Radioactivity Content ${ }^{1}, \mathrm{Ci}$

$\left.\begin{array}{ll}{ }^{46} \mathrm{Sc} & 0.0074 \\ 54 \mathrm{Mn} & 0.036 \\ 60 \mathrm{Co} & 0.22 \\ 65 \mathrm{Zn} & 0.71\end{array}\right\}[\mathrm{c}]$




\section{Footnotes for Table A-1}

1. The letters in brackets in the table indicate the technique ( 1 isted below) used for measuring the radioactivity content of wastes emplaced in the lysimeters.

[A] = Counted with the Separations Control Laboratory (B1dg. 772-F) Waste Monitor, employing a NS-633 multi-channe1 analyzer and an ORTEC $8108-0320 \mathrm{Ge}-\mathrm{Li}$ detector. ${ }^{239} \mathrm{Pu}$ was detected by counting the $129 \mathrm{mev}$ photons, and $238 \mathrm{Pu}$ was detected by counting the $153 \mathrm{mev}$ photons.

[B] $={ }^{14} \mathrm{C}$ was extracted from moderator resin by bicarbonate exchange and counted by liquid scintillation. Finally, combustion of the resin and collection and counting of $\mathrm{CO}_{2}$ showed no residual ${ }^{14} \mathrm{C}$ in the resin.

[C] = Counted with the gamma monitor used for surveying incoming waste at the burial ground. This monitor has been evaluated and described.

[D] = Counted with the Savannah River Laboratory Waste Monitor, employing a Canberra $8100-4 \mathrm{~K}$ multi-channel analyzer, a Canberra 7705 planar LC detector and a PDP-11-16A computer processing unit. The $17 \mathrm{kev}$ photons were used for detecting $238 \mathrm{Pu}$ and the $59.5 \mathrm{kev}$ photons were used for detecting $241_{\mathrm{Am}}$.

[E] = Three-inch long samples were taken from both ends and the middle of both pipe jumpers used. These samples were counted with an alpha probe, then the radioactivity was dissolved from them with three successive exposures to $\mathrm{HNO}_{3}-\mathrm{HF}$ solution. Probe data and final leach solution data both indicated no significant residual radioactivity on the samples. The curies present on the samples was obtained by analyses of the leach solution. The curies 'of radioactivity placed in the lysimeters was determined by assuming that the amount of radioactivity on the pipe was uniform and thus directly proportional to the length of the pipe.

$[F]=$ Standard 1aboratory and counting room techniques, possibly including chemical separations, alpha or beta counting, gamma spectrometry, etc.

2. Based on simultaneous analys is of packages for all five lysimeters.

3. Calculations have shown that certain non-gamma emitting radioisotopes are likely to be present [e.g. ${ }^{63} \mathrm{Ni}(100 \mathrm{yrs}) ; 9$ and $55 \mathrm{Fe}(2.7$ yrs $)]$ due to neutron capture reactions, but the amount is uncertain due to variations in the composition of aluminum and stainless steels used in reactor components. The amount of these radioisotopes in the scrap loaded into the lysimeters was not determined. 
